\title{
Mycotoxins: Biotransformation and Bioavailability Assessment Using Caco-2 Cell Monolayer
}

\author{
Van Nguyen Tran, Jitka Viktorová@ and Tomáš Ruml * \\ Department of Biochemistry and Microbiology, University of Chemistry and Technology, Technicka 3, \\ 16628 Prague 6, Czech Republic; tranv@vscht.cz (V.N.T.); prokesoj@vscht.cz (J.V.) \\ * Correspondence: rumlt@vscht.cz; Tel.: +420-220-443-021
}

Received: 12 June 2020; Accepted: 18 September 2020; Published: 30 September 2020

\begin{abstract}
The determination of mycotoxins content in food is not sufficient for the prediction of their potential in vivo cytotoxicity because it does not reflect their bioavailability and mutual interactions within complex matrices, which may significantly alter the toxic effects. Moreover, many mycotoxins undergo biotransformation and metabolization during the intestinal absorption process. Biotransformation is predominantly the conversion of mycotoxins meditated by cytochrome P450 and other enzymes. This should transform the toxins to nontoxic metabolites but it may possibly result in unexpectedly high toxicity. Therefore, the verification of biotransformation and bioavailability provides valuable information to correctly interpret occurrence data and biomonitoring results. Among all of the methods available, the in vitro models using monolayer formed by epithelial cells from the human colon (Caco-2 cell) have been extensively used for evaluating the permeability, bioavailability, intestinal transport, and metabolism of toxic and biologically active compounds. Here, the strengths and limitations of both in vivo and in vitro techniques used to determine bioavailability are reviewed, along with current detailed data about biotransformation of mycotoxins. Furthermore, the molecular mechanism of mycotoxin effects is also discussed regarding the disorder of intestinal barrier integrity induced by mycotoxins.
\end{abstract}

Keywords: permeability; bioavailability; intestinal transport; metabolism; mycotoxins; biotransformation; cytochrome

Key Contribution: The paper overviews the biotransformation of mycotoxins in order to transform the toxins to harmless metabolites. However, it may possibly generate products exerting unexpectedly high toxicity.

\section{Introduction}

Mycotoxins are toxic secondary metabolites secreted by fungi and frequently occurring in food and feed worldwide [1-3]. The major fungal genera producing foodborne mycotoxins are Fusarium, Aspergillus, Penicillium, and Alternaria [4,5]. Fusarium is one of the most important producers of toxins falling into the three major classes of mycotoxins, such as fumonisins (FBs), zearalenone (ZEA), trichothecenes (deoxynivalenol (DON), nivalenol (NIV), and T-2 and HT-2 toxins, and also emerging mycotoxins involving beauvericin (BEA) and enniatins (ENNs) [6,7]. Ochratoxin A (OTA), the major mycotoxin of the ochratoxins, is produced by various species of the Aspergillus and Penicillium genus [8]. In addition, Penicillium species are known to produce mycophenolic acid (MPA) [9] and patulin (PAT) $[10,11]$. Aflatoxins, including aflatoxin B1 (AFB1), aflatoxin B2 (AFB2), aflatoxin M1 (AFM1), aflatoxin M2 (AFM2), aflatoxin G1 (AFG1), and aflatoxin G2 (AFG2), are the most studied group of mycotoxins produced by Aspergillus flavus [12,13]. Alternaria fungi contaminate a wide variety of food items, such as cereals, fruits, wheat, barley, and sorghum, producing several toxins, with alternariol 
$(\mathrm{AOH})$, alternariol monomethyl ether (AME), tentoxin (TEN), tenuazonic acid (TeA), altenuene (ALT), and altertoxins (ATXs) being the most relevant ones [14,15]. The effects of mycotoxins on cell functions are listed in Table 1.

Table 1. Toxic effects of mycotoxins.

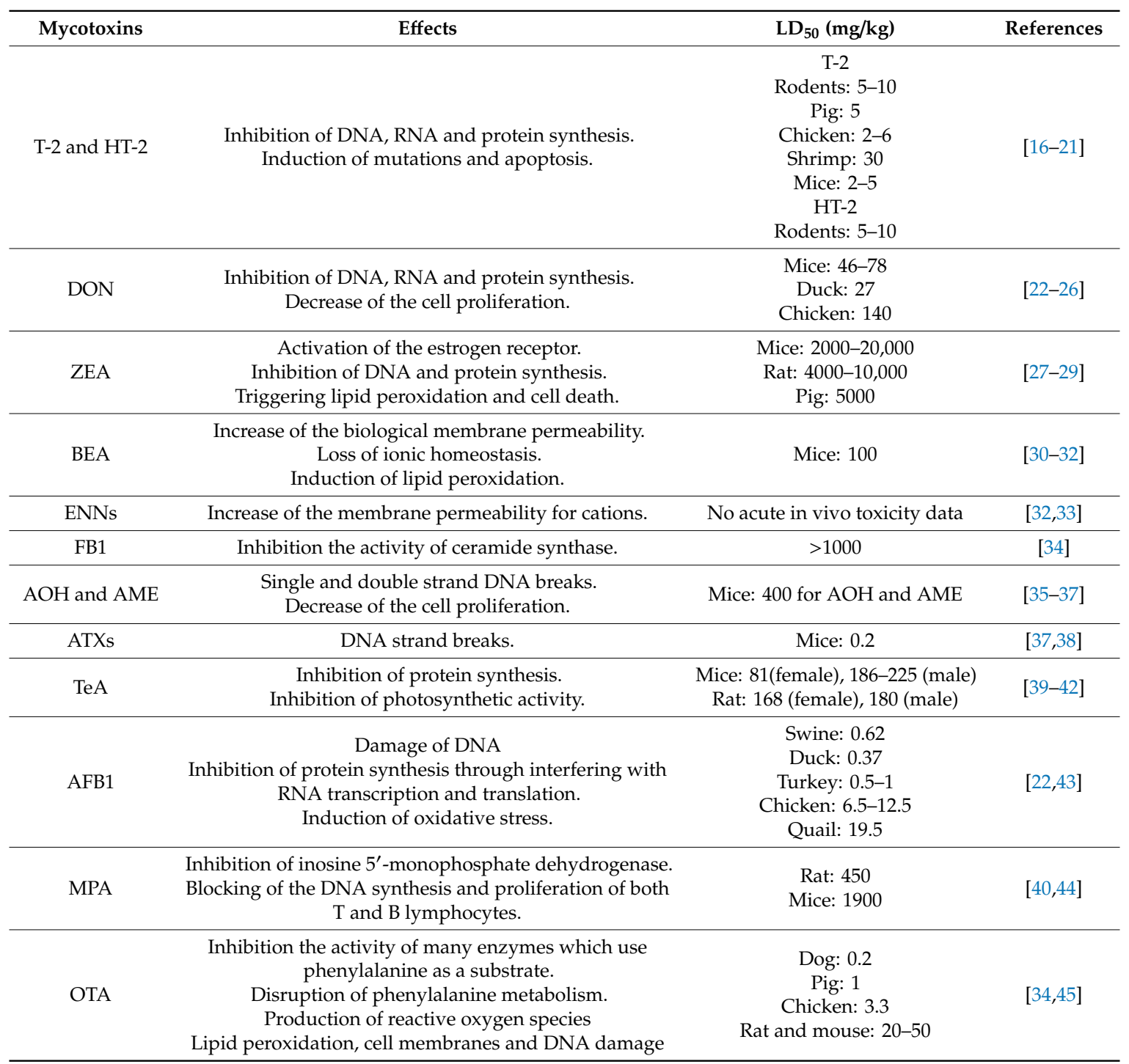

T-2 toxin (T-2), HT-2 toxin (HT-2), deoxynivalenol (DON), zearalenone (ZEA), beauvericin (BEA), enniatins (ENNs), fumonisin B1 (FB1), alternariol (AOH), alternariol monomethyl ether (AME), altertoxins (ATXs), tenuazonic acid

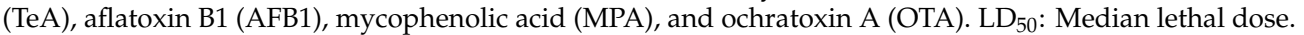

The naturally ubiquitous occurrence of mycotoxins in food has been widely documented (Table 2). Thus, mycotoxins can contaminate a variety of foodstuffs, such as grain-based products (wheat, oats, barley, maize, and rye), nuts, dried fruits, spices, cocoa, coffee, beer, wine, fruits, meat, and animal products (eggs, milk, and cheese) [14,46-50]. Some mycotoxins are thermostable, allowing them to endure most food processes [51]. DON is stable up to $120-180{ }^{\circ} \mathrm{C}$ and was degraded after $40 \mathrm{~min}$ at $210{ }^{\circ} \mathrm{C}$ [52]. For ZEA, heat treatment at temperatures up to $160^{\circ} \mathrm{C}$ had no significant effect and $85 \%$ reduction of the toxin concentration in barley flours was achieved after $60 \mathrm{~min}$ at $220^{\circ} \mathrm{C}$ [53]. DON content in whole and white breads decreased by $49 \%$ and $39 \%$, respectively, compared to the original flours [51]. According to Generotti et al. [54], increasing $\mathrm{pH}$ and baking time in an acceptable technological range can reduce DON concentration in the final product [54]. T-2 and HT-2 are relatively stable during the thermal process up to $170{ }^{\circ} \mathrm{C}$ and about $45 \%$ of T-2 and $20 \%$ HT-2 were thermally degraded during biscuit-making [55]. Similarly, the loss of OTA, ZEA, AFB1, 
BEA, and ENNs in the products showed that thermal processing effectively decreased the content of these mycotoxins [52,56,57]. The 54\% AOH reduction was reported for treatment at $110{ }^{\circ} \mathrm{C}$ for $20 \mathrm{~min}$, whereas no significant effect was found for AME at the same temperature [58]. Based on Stadler et al. [59], the parent mycotoxin can be structurally modified during food processing, including isomerization, decarboxylation, rearrangements, and the reaction with other small molecules [59]. In summary, food processing such as brewing, cooking, baking, frying, canning flaking, nixtamalization, and extrusion, in general, reduced concentrations of some mycotoxins but did not eliminate them completely $[52,59,60]$.

Table 2. Occurrence of mycotoxins in food commodities.

\begin{tabular}{|c|c|c|c|c|}
\hline Mycotoxins & Commodity & Concentration Range $(\mu \mathrm{g} / \mathrm{kg})$ & Country & References \\
\hline \multirow{4}{*}{ T-2 and HT-2 } & Barley grain & $26-787$ & Italy & \multirow{4}{*}[61,62]{} \\
\hline & Maize & 146 & Hungary & \\
\hline & Cereal-based products & $<$ LOD-209 & Tunisia & \\
\hline & Wheat & $6.7-15.2$ & Spain & \\
\hline \multirow{4}{*}{$\mathrm{DON}$} & Cereal and corn & $96-1790$ & Portugal & \multirow{4}{*}[63,64]{} \\
\hline & Wheat-based product & $333-1821$ & Portugal & \\
\hline & Maize grain & ND-700 & Ethiopia & \\
\hline & Sorghum grain & $40-112$ & Ethiopia & \\
\hline \multirow{3}{*}{ ZEA } & Corn & $59-505$ & Philippines & \multirow{3}{*}{ [63-65] } \\
\hline & Cereal and corn & $5-930$ & Portugal & \\
\hline & Sorghum grain & $7.2-382$ & Ethiopia & \\
\hline \multirow{2}{*}{ BEA } & Rice & $3800-26,300$ & Morocco & \multirow{2}{*}[46]{} \\
\hline & Cereal & $0.1-10,600$ & Morocco & \\
\hline ENN A & Rice & $8400-119,500$ & Morocco & \multirow{4}{*}[46]{} \\
\hline ENN A1 & Rice & $56,200-448,700$ & Morocco & \\
\hline ENN B & Rice & $4400-26,200$ & Morocco & \\
\hline ENN B1 & Rice & $3600-23,700$ & Morocco & \\
\hline \multirow{5}{*}{ FB1 } & Maize & ND-1106 & Zimbabwe & \multirow{5}{*}[3,63]{} \\
\hline & Industrial processed food & 43-836 & Nigeria & \\
\hline & Dried sweet potato chips & $29.34-628.78$ & Tanzania & \\
\hline & Corn & $113-1162$ & Portugal & \\
\hline & Corn products & 183-2026 & Portugal & \\
\hline \multirow{5}{*}{$\mathrm{AOH}$} & Tomato sauce & $1.2-20.8$ & Europe & \multirow{5}{*}[46,64,66]{} \\
\hline & Sunflower oil & $0.7-2.9$ & Europe & \\
\hline & Sorghum grain & $75-1090$ & Ethiopia & \\
\hline & Cereal & $0.75-832$ & Germany & \\
\hline & Fruit juices & $15-100$ & Germany & \\
\hline \multirow{5}{*}{ AME } & Tomato sauce & $<$ LOQ-4.7 & Europe & \multirow{5}{*}[46,64,66]{} \\
\hline & Sunflower oil & $<$ LOQ-7.1 & Europe & \\
\hline & Sorghum grain & $13-257$ & Ethiopia & \\
\hline & Cereal & $0.3-905$ & Germany & \\
\hline & Fruit juices & $0.13-4.9$ & Germany & \\
\hline \multirow{2}{*}{ ALT } & Tomato products & $6.1-62$ & Belgium & \multirow{2}{*}{ [46] } \\
\hline & Fruit juices & $1.18-18.4$ & Germany & \\
\hline \multirow{2}{*}{ ATXs } & Tomato sauce & $0.5-3.7$ & Europe & \multirow{2}{*}[66]{} \\
\hline & Sunflower oil & $2-4.7$ & Europe & \\
\hline \multirow{4}{*}{$\mathrm{TeA}$} & Tomato sauce & $<$ LOQ-691 & Europe & \multirow{4}{*}[46,66]{} \\
\hline & Sunflower oil & $24-458$ & Europe & \\
\hline & Fruit juices & $1.1-250$ & Germany & \\
\hline & Infant food & $0.8-1200$ & Germany & \\
\hline
\end{tabular}


Table 2. Cont.

\begin{tabular}{|c|c|c|c|c|}
\hline Mycotoxins & Commodity & Concentration Range $(\mu \mathrm{g} / \mathrm{kg})$ & Country & References \\
\hline \multirow{3}{*}{ TEN } & Tomato sauce & $0.2-1.2$ & Europe & \multirow{3}{*}[46,66]{} \\
\hline & Sunflower oil & $<$ LOQ-21.8 & Europe & \\
\hline & Fruit juices & $0.5-10.7$ & Germany & \\
\hline \multirow{2}{*}{ AFB1 } & Polished rice & $1-2546$ & Philippines & \multirow{2}{*}[64,65]{} \\
\hline & Sorghum grain & $<7.5-359$ & Ethiopia & \\
\hline \multirow{2}{*}{ PAT } & Apples & $3.2-1500$ & Portugal & \multirow{2}{*}{ [63] } \\
\hline & Quince jam & $9.7-28.7$ & Portugal & \\
\hline \multirow{3}{*}{ OTA } & Cereals & $0.27-7.97$ & Portugal & \multirow{3}{*}{ [63-65] } \\
\hline & Coffee beans & $8-36,561$ & Philippines & \\
\hline & Sorghum grain & $3.7-163$ & Ethiopia & \\
\hline
\end{tabular}

LOQ: Limit of quantitation; ND: Not detected.

Ingestion of contaminated food is considered as a major route for exposure to many mycotoxins [51]. Upon ingestion, mycotoxins may induce local toxicity or cross the intestinal barrier to enter the bloodstream and reach target organs [2]. Nevertheless, to achieve any effect in a specific tissue or organ, the mycotoxins must be available in effective concentration at certain location, which refers to the compound's tendency to be extracted from the food matrix, and they must then be absorbed from the gut via the intestinal cells [67]. The term bioaccessibility refers to the fraction of a mycotoxin liberated from a food matrix that passes unmodified through complex biochemical reactions related to the gastrointestinal digestion and thus becomes available for absorption in the small intestine $[68,69]$. Bioaccessibility can be considered as an indicator for the maximal absorption of the toxin, which can be used for realistic worst-case risk assessment of the toxin in a consumer product [70]. In fact, foodborne mycotoxins can be degraded or modified by metabolic processes of the human body, and only a fraction of the initial content can pass the intestinal membrane to enter the bloodstream [71]. In this sense, bioavailability is defined as the portion of ingested contaminant in food that reaches the systemic circulation [72].

To determine the bioavailability of mycotoxins, different in vitro models or in vivo experiments have been carried out. In vivo experiments would be the best way to evaluate the efficacy of binding capacities [73]. However, to avoid the ethically questionable use of animals in the in vivo experiments, the in vitro models have been used instead. The bioavailability studies carried out in animals are complex, expensive, and lengthy, while the in vitro experiments can be simple, rapid, and cost-effective [72]. The advantages and disadvantages of each procedure are summarized in Table 3. Most of the in vitro studies of the gut were done with human colon tumorigenic cell lines Caco-2, T84, TC7, and HT-29 [74]. The brief description of the expression of transporters, enzymes, and other relevant proteins of available cell lines used for the in vitro biotransformation and bioavailability of drugs and xenobiotics is stated in Table 4. Among commercially available cell lines, Caco- 2 cells have been widely used to study absorption, metabolism, and bioavailability of drugs and xenobiotics [2,74]. This model is generally suitable for screening drug and nutrient compounds due to a good in vitro-in vivo correlation [75]. 
Table 3. Advantages and disadvantages of in vivo and in vitro models in the evaluation of bioavailability.

\begin{tabular}{|c|c|c|}
\hline Models & Advantages & Disadvantages \\
\hline \multicolumn{3}{|l|}{ In vitro models } \\
\hline $\begin{array}{l}\text { Simulation of gastrointestinal } \\
\text { transformation }\end{array}$ & $\begin{array}{l}\text { Similar to the physiological processes in the } \\
\text { human body } \\
\text { Suitable for high-throughput format } \\
\text { Ability of testing a specific mechanisms of action } \\
\text { Focus on small number of components } \\
\text { Validation with reference material }\end{array}$ & $\begin{array}{c}\text { No hormonal and nervous control } \\
\text { Lack of feedback mechanisms } \\
\text { Absence of mucosal cell activity } \\
\text { Deficiency of complexity of peristaltic } \\
\text { movements, and involvement of the local } \\
\text { immune system } \\
\text { Homeostatic mechanisms are not present } \\
\text { Difficult to achieve the anaerobic } \\
\text { assay conditions }\end{array}$ \\
\hline Caco-2 cells & $\begin{array}{c}\text { Reproducibility of results } \\
\text { Provides information about efficiency of } \\
\text { digestion, absorption } \\
\text { Ability of studying transport mechanisms } \\
\text { Phenotypically similar to absorptive } \\
\text { epithelial cells } \\
\text { Suitable for high-throughput format }\end{array}$ & $\begin{array}{c}\text { Human colonic adenocarcinoma origin } \\
\text { Higher TEER value than human intestine } \\
\text { Lack of mucin, microflora, biofilms, } \\
\text { and epithelial cell types } \\
\text { Variation of efflux transporters } \\
\text { expression levels } \\
\text { Incapability of simulating the changes of } \mathrm{pH}\end{array}$ \\
\hline In vivo models & $\begin{array}{c}\text { In vivo condition } \\
\text { Well-known biology } \\
\text { Selection of specific subjects } \\
\text { Better-understanding kinetic of mycotoxins }\end{array}$ & $\begin{array}{c}\text { High-throughput limitation } \\
\text { Extremely complex functional systems } \\
\text { Influence of different } \\
\text { factors-phenotypic variation } \\
\text { Lack of certified reference standards } \\
\text { Ethical issues and high cost } \\
\text { Time consuming and labor intensive }\end{array}$ \\
\hline
\end{tabular}

TEER: Transepithelial electrical resistance.

Table 4. Available human and animal cell lines used for in vitro biotransformation and bioavailability of drugs and xenobiotics.

\begin{tabular}{cccc}
\hline Cell line & Origin & $\begin{array}{c}\text { Transporters, Enzymes and Other } \\
\text { Relevant Proteins }\end{array}$ & References \\
\hline Caco-2 & $\begin{array}{c}\text { Human colon } \\
\text { adenocarcinoma }\end{array}$ & $\begin{array}{c}\text { CYP1A1, 1A2 } \\
\text { GST, UGT, SULT, NAT } \\
\text { P-gp, MRP-2, BCRP }\end{array}$ & {$[76-78]$} \\
\hline HT-29 & $\begin{array}{c}\text { Human colon } \\
\text { adenocarcinoma }\end{array}$ & $\begin{array}{c}\text { CYP2C8, CYP2J2, CYP3A4 } \\
\text { GST, UGT } \\
\text { MRP1, MRP2, p-gp, BCRP }\end{array}$ & {$[$ [79-81] } \\
\hline TC-7 & Caco-2 subclones & Similar to Caco-2 & {$[82]$} \\
\hline T84 & Human colonic carcinoma & P-gp, MRP2, MRP3 & {$[83,84]$} \\
\hline H4 & Human small foetal intestine & CYP3A4 & {$[85]$} \\
\hline IPEC-J2 & Neonatal pig small intestine & $\begin{array}{c}\text { CYP1A1, 1A2, 3A29 } \\
\text { P-gp, MRP1, BCRP }\end{array}$ & {$[86,87]$} \\
\hline
\end{tabular}

P-glycoprotein (P-gp), multidrug resistance protein (MRP), breast cancer resistance protein (BCRP), uridinediphosphoglucuronosyl transferase (UGT), sulfotransferase (SULT), N-acetyltransferase (NAT), glutathione-S-transferase (GST), and cytochrome P (CYP).

This review mainly focuses on the biotransformation of mycotoxins via the expression regulation of some critical enzymes and the currently available data regarding the in vitro study of the bioavailability of mycotoxins using the Caco-2 monolayer. Furthermore, the usefulness and limitations of this model are also discussed.

\section{Biotransformation of Mycotoxins}

Mycotoxins biotransformation is defined as all the complex modifications which alter the structure of mycotoxins by chemical reactions within the body [88]. Biotransformation is often referred to detoxification, but biotransformation enzymes can also convert certain chemicals into highly toxic 
metabolites (Figure 1) in a process known as bioactivation [89]. Biotransformation of mycotoxins involves two distinct stages, namely phase I and phase II. The biotransformation process allows metabolites created during phase I to enter conjugation processes (phase II), but in some cases, the substances may be eliminated directly after phase I [90].

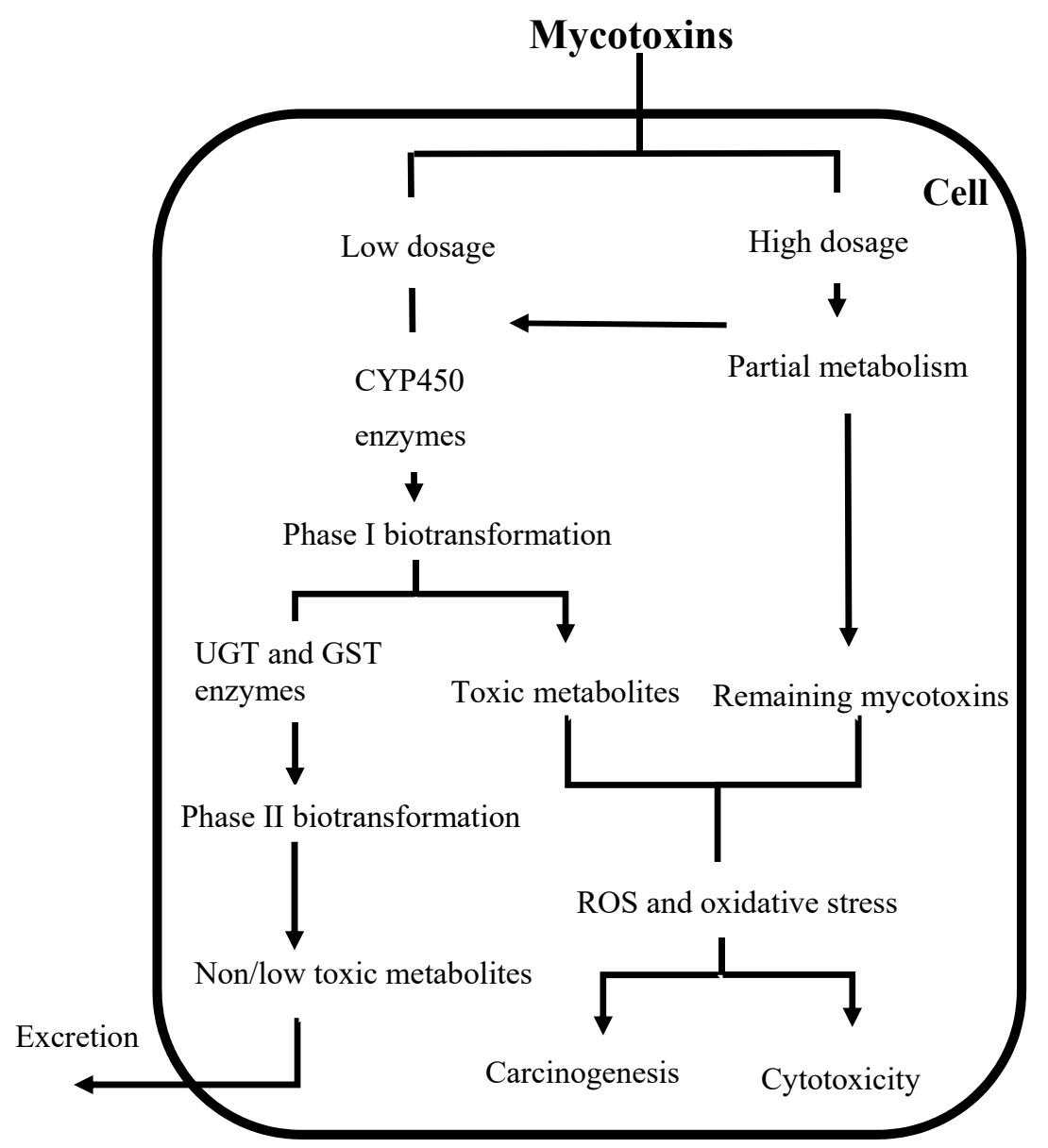

Figure 1. Major biotransformation and adverse cellular effects of mycotoxins. CYP450: Cytochrome P450; UGT: Uridine 5'-diphospho-glucuronosyltransferase; GST: Glutathione S-transferase; ROS: Reactive oxygen species.

In phase I, the mycotoxin could be oxidized, reduced, or hydrolyzed based on their chemical structure [90]. The enzymes involved in detoxification belong to the cytochrome P (CYP) superfamily. The CYP superfamily contains the enzymes involved in oxidative metabolism, such as monooxygenases, prostaglandin synthases, amine oxidases and alcohol dehydrogenases; and reductive metabolism mainly governed by epoxide hydrolases, and aldehyde or ketone reductases [91]. CYP450 enzymes play an important role in the oxidative and reductive metabolism of many endogenous or exogenous chemical compounds [34], including most mycotoxins (Table 5). In mammals, CYPs are present in the endoplasmic reticulum and mitochondria of most cells [89]. Among CYPs, CYP3A with an average content from $50-70 \%$ of total enteric CYPs is the major subfamily expressed in the human small intestine [92]. 
Table 5. CYP450 isoforms induced by mycotoxins and their phase I and II metabolites.

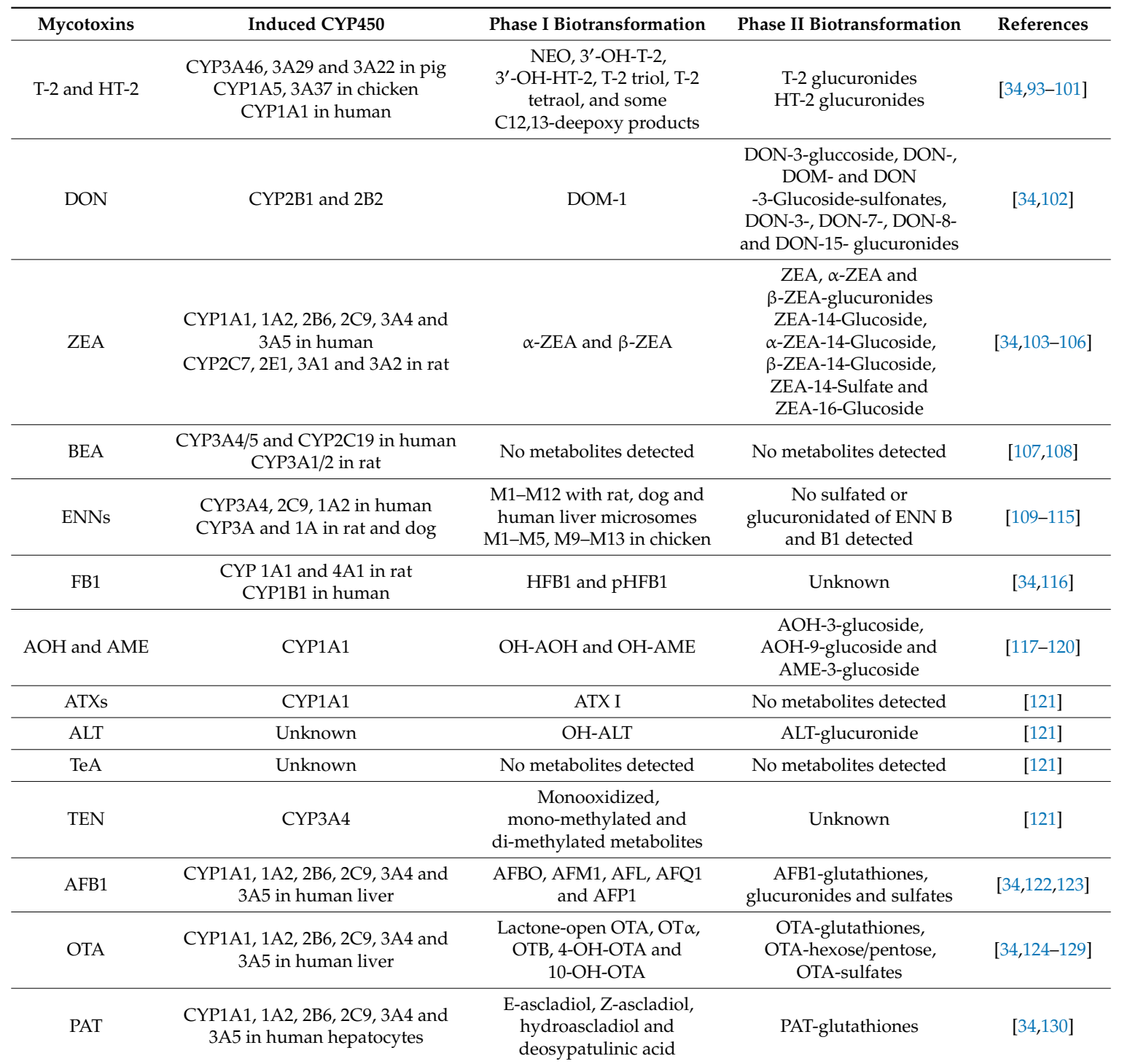

T-2 toxin (T-2), HT-2 toxin (HT-2), neosolaniol (NEO), deoxynivalenol (DON), zearalenone (ZEA), beauvericin (BEA), enniatins (ENNs), fumonisin B1 (FB1), alternariol (AOH), alternariol monomethyl ether (AME), altenuene (ALT), altertoxins (ATXs), tenuazonic acid (TeA), Tentoxin (TEN), aflatoxin B1 (AFB1), mycophenolic acid (MPA), ochratoxin A (OTA), patulin (PAT), 3'-hydroxy-T-2 (3'-OH-T-2), 3'-hydroxy-HT-2 (3'-OH-HT-2), hydroxy-alternariol $(\mathrm{OH}-\mathrm{AOH})$, hydroxy-alternariol monomethyl ether (OH-AME), deepoxy-deoxynivalenol (DOM-1), $\alpha$-zearalenone ( $\alpha$-ZEA), $\beta$-zearalenone ( $\beta$-ZEA), hydroxy-altenuene (OH-ALT), AFB1-8,9-epoxide (AFBO), aflatoxin M1 (AFM1), aflatoxicol (AFL), aflatoxin Q1 (AFQ1), aflatoxin P1 (AFP1), ochratoxin $\alpha(\mathrm{OT} \alpha)$, ochratoxin B (OTB), 4-hydroxy-OTA (4-OH-OTA) and 10-hydroxy-OTA (10-OH-OTA), cytochrome P (CYP).

Phase II reactions are known as conjugation reactions, which usually refer to covalent binding of endogenous hydrophilic substances such as glucuronic acid and sulfate. The reactions provide more hydrophilic compounds, which are quickly eliminated. In general, phase II reactions decrease the toxicity [89]. Uridine 5'-diphospho-glucuronosyltransferase (UDP-glucuronosyltransferase-UGT) and glutathione S-transferase (GST) enzymes play an important role in the phase II metabolism [89,91].

Although the liver is the main detoxification organ, extrahepatic tissues in the gastrointestinal tract (GI tract), kidney, and bladder also show metabolic activity. The GI tract is a first physical barrier for mycotoxins but it also influences the biotransformation process and bioavailability of mycotoxins in other ways. Microorganisms from guts have been reported to exhibit the capacity for degrading mycotoxins [131-134]. Additionally, P-glycoprotein (P-gp) and multidrug resistance protein (MRP), members of the ATP-binding cassette (ABC) superfamily of transport proteins, are able to pump mycotoxins out of the intestinal cells, leading to limit bioavailability of the substrates [71,135]. 
Both CYP450 and P-gp in the gut play a crucial role in defense mechanisms against mycotoxins that reach the intestinal mucosa [92].

Previous biotransformation studies mainly focused on AFB1, OTA, trichothecenes (T-2 and DON), ZEA, and FBs. Recently, emerging Fusarium and Alternaria mycotoxins have gained more interest [46], although in vivo metabolization data are still limited. The biotransformation products of mycotoxins are summarized in Table 3. These studies revealed that mycotoxins can induce the expression of CYP450 enzymes in animal and human cell lines.

\subsection{Biotransformation of Aflatoxins}

Native AFB1 itself is not toxic, but the bioactivation by cytochrome CYP450 leads to AFB1-8,9epoxide (AFBO), which is acutely toxic, mutagenic, and carcinogenic (Figure 2) [34]. Additionally, the metabolic pathway of AFB1 can also give rise to moderately toxic aflatoxicol (AFL) by ketoreduction, mildly toxic AFM1 and relatively nontoxic aflatoxin Q1 (AFQ1) by hydroxylation, and relatively nontoxic aflatoxin P1 (AFP1) by demethylation $[123,136]$. Their formation is thus considered as a detoxification pathway [137]. CYP enzymes, particularly CYP1A2 and CYP3A4, are predominant in the metabolic activation of AFB1 [122]. The detoxification of AFBO and AFM1 is realized by conjugation with glutathione catalyzed by GST. Otherwise, the unconjugated AFBO is alternatively hydrolyzed to AFB1-dihydrodiol, which is reversibly converted to AFB1-dialdehyde [34,90,138]. AFB1-dialdehyde is metabolized by the enzymes of aldo-keto reductase subfamily 7 (AKR7) and microsomal epoxide hydrolase $(\mathrm{mEH})$ to form the nontoxic AFB1-dialcohol metabolite in humans, rats, mice, and pigs $[123,139,140]$.

\subsection{Biotransformation of Ochratoxin $A$}

In animals and humans, OTA can be metabolized by both phase I and phase II enzymes to many different products in the liver, kidney, and intestine (Figure 3). Poor biotransformation and slow elimination of metabolites contribute to the toxicity, carcinogenicity, and organ specificity of OTA $[139,141]$. In the gut, ochratoxin $\alpha(\mathrm{OT} \alpha)$, a major metabolite and is formed by carboxypeptidases, which cleave the peptide bond in OTA [34]. Other types of major metabolites of OTA are 4-hydroxyochratoxin A (4-OH-OTA) and 10-hydroxyochratoxin A (10-OH-OTA) have been identified from the urine of rats and are also produced by human, pigs, goat, chicken, rat, and rabbit liver microsomes or human bronchial epithelial cells in vitro [142-144]. Most of the metabolites of OTA, such as OT $\alpha$, OTB, 4-OH-OTA, and 10-OH-OTA, are less toxic than the original compound $[129,139]$. However, opening the lactone ring under alkaline conditions (called the lactone-opened OTA), found in rodents, leads to more toxic metabolites than OTA itself [126]. These phase I-type reactions probably relate to the action of the CYP450 enzyme family, including CYP1A1, CYP1A2, CYP3A1, CYP3A2, CYP3A4, CYP3A5, CYP2B6, and CYP2C9 [124-126]. Phase II biotransformation mainly occurs in the liver with conjugation of OTA with sulfate, glucuronide, hexose/pentose, and glutathione [127-129]. 


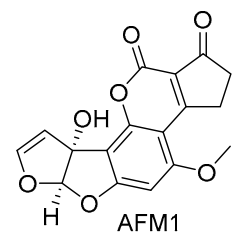

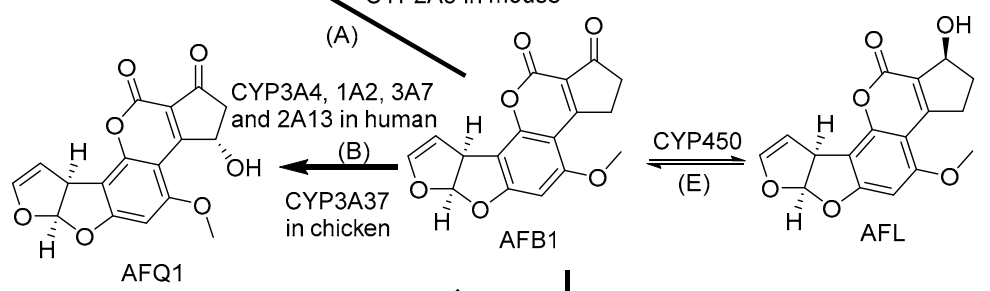<smiles>O=C1CCc2c1c(=O)oc1c3c(cc(O)c21)O[C@@H]1OC=C[C@H]31</smiles>

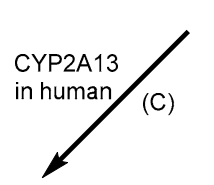

CYP1A2, $2 A 13$ and $3 A 4$ in human CYP1A1, 1A5, 2A6 and 3A37 in chicken

(D)

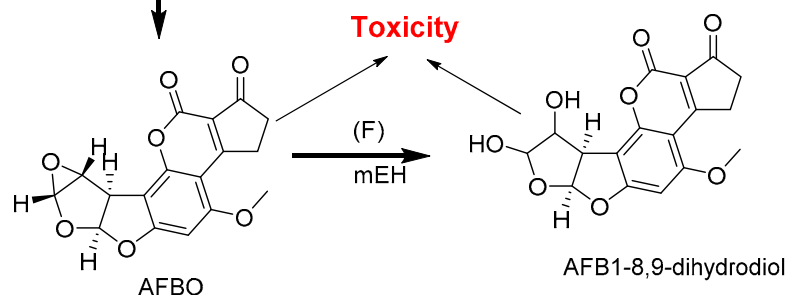

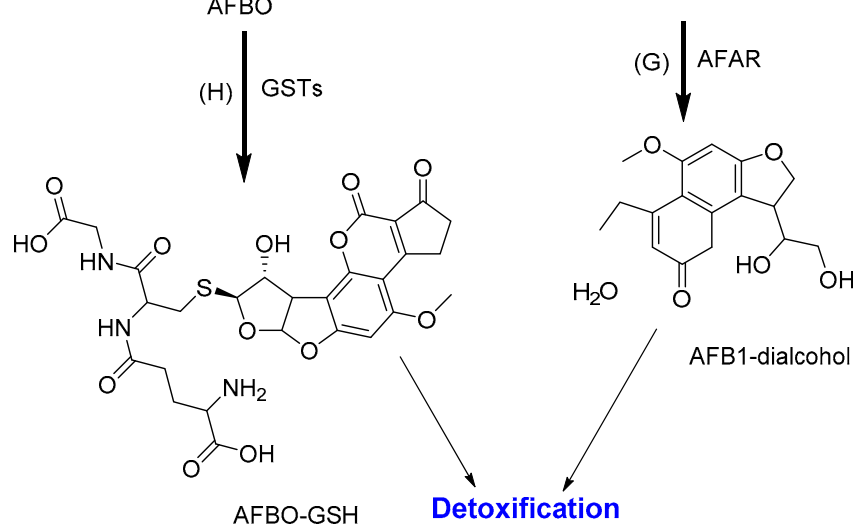

Figure 2. The major metabolic pathways of aflatoxin B1 (AFB1): (A) Aflatoxin M1 (AFM1) and (B) aflatoxin Q1 (AFQ1) by hydroxylation; (C) Aflatoxin P1 (AFP1) by demethylation; (D) AFB1-8,9-epoxide (AFBO) by epoxidation; (E) Aflatoxicol (AFL) by ketoreduction; (F) AFB1-8,9-dihydrodiol by microsomal epoxide hydrolase (mEH); (G) AFB1-dialcohol by aflatoxin-aldehyde reductase (AFAR); and (H) AFBO-glutathione (AFBO-GSH) by conjugation with glutathione. CYP: Cytochrome P; GSTs: Glutathione S-transferases [123]. 


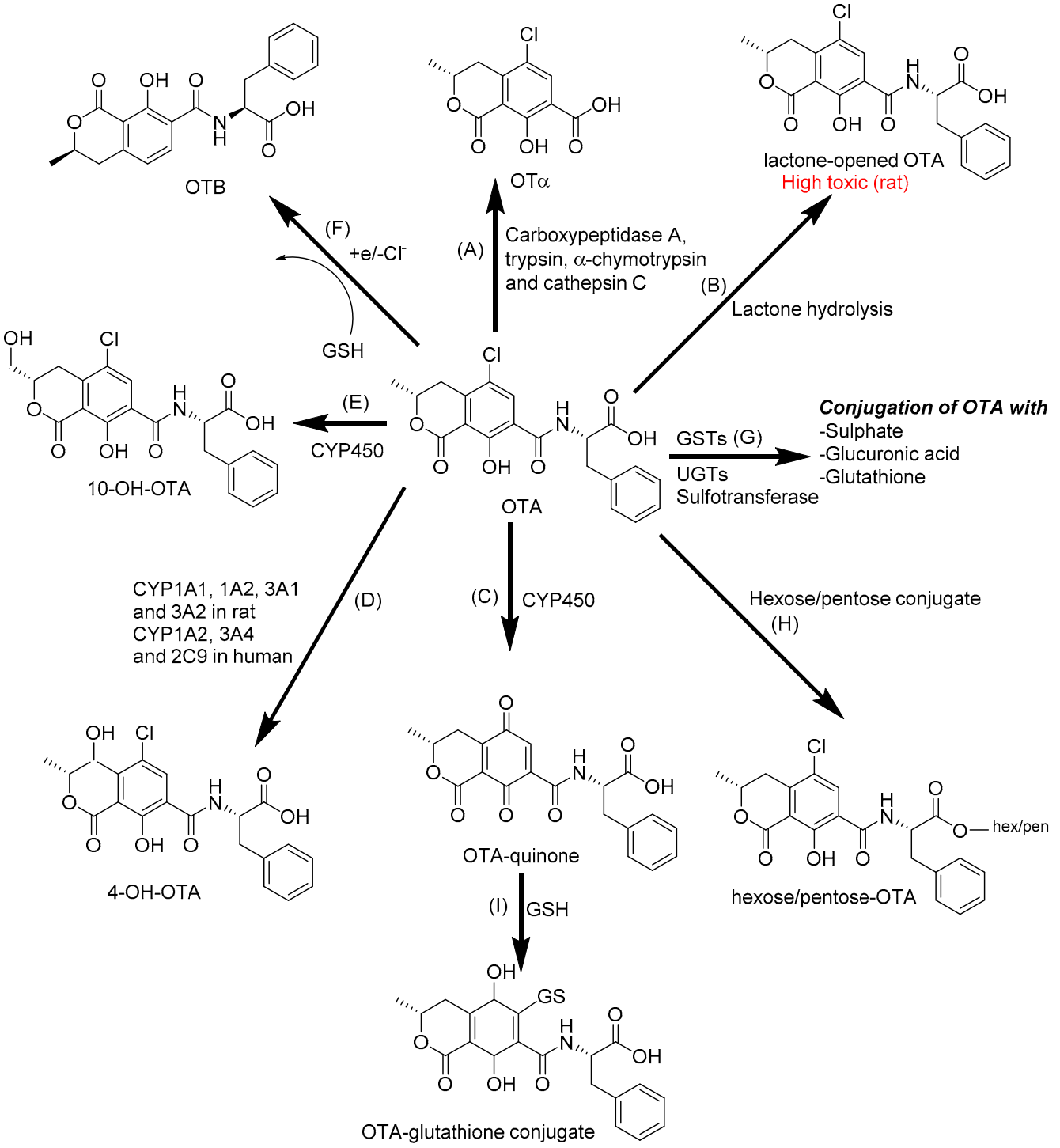

Figure 3. The biotransformation of ochratoxin A (OTA): (A) OT $\alpha$ by cleavage of the peptide bond of OTA; (B) lactone-opened OTA by lactone hydrolysis; (C) OTA-quinone by oxidation; (D) 4-hydroxyochratoxin A (4-OH-OTA) and (E) 10-hydroxyochratoxin A (10-OH-OTA) by hydroxylation; (F) OTB by dechlorination; (G) OTA-glutathione, OTA-glucuronide and OTA-sulfate by conjugation with glutathione (GSH), glucuronic acid, and sulfate; (H) Hexose/pentose-OTA by conjugation with hexose/pentose, (I) OTA-glutathione by conjugation with glutathione. CYP450: Cytochrome P450; GSTs: Glutathione S-transferases; UGTs: Uridine 5'-diphospho-glucuronosyltransferases [129].

\subsection{Biotransformation of Deoxynivalenol}

DON is not substrate of phase I metabolism [145]. Major metabolites of DON include the glucuronide and sulphate conjugates of DON (Figure 4) and deepoxy-deoxynivalenol (DOM-1) [146]. DOM-1 showed lower cytotoxicity in pigs [147]. DON conjugates with glycosides or sulfonates to form DON-3-gluccoside (D3G); DON-, DOM- and D3G-sulfonates; and DON-3-, DON-7-, DON-8-, and DON-15- glucuronides identified in porcine, rat, chicken, bovine, and human [34,102,148-150]. Other DON-biotransformation products, including DON-glutathione conjugates and the products of glutathione degradation, such as DON-S-cysteinyl-glycine and DON-S-cysteine, have been reported in cereals. Thanks to intestinal microflora, DON could be metabolized in animals and humans but not deposited in the tissues [151,152]. 


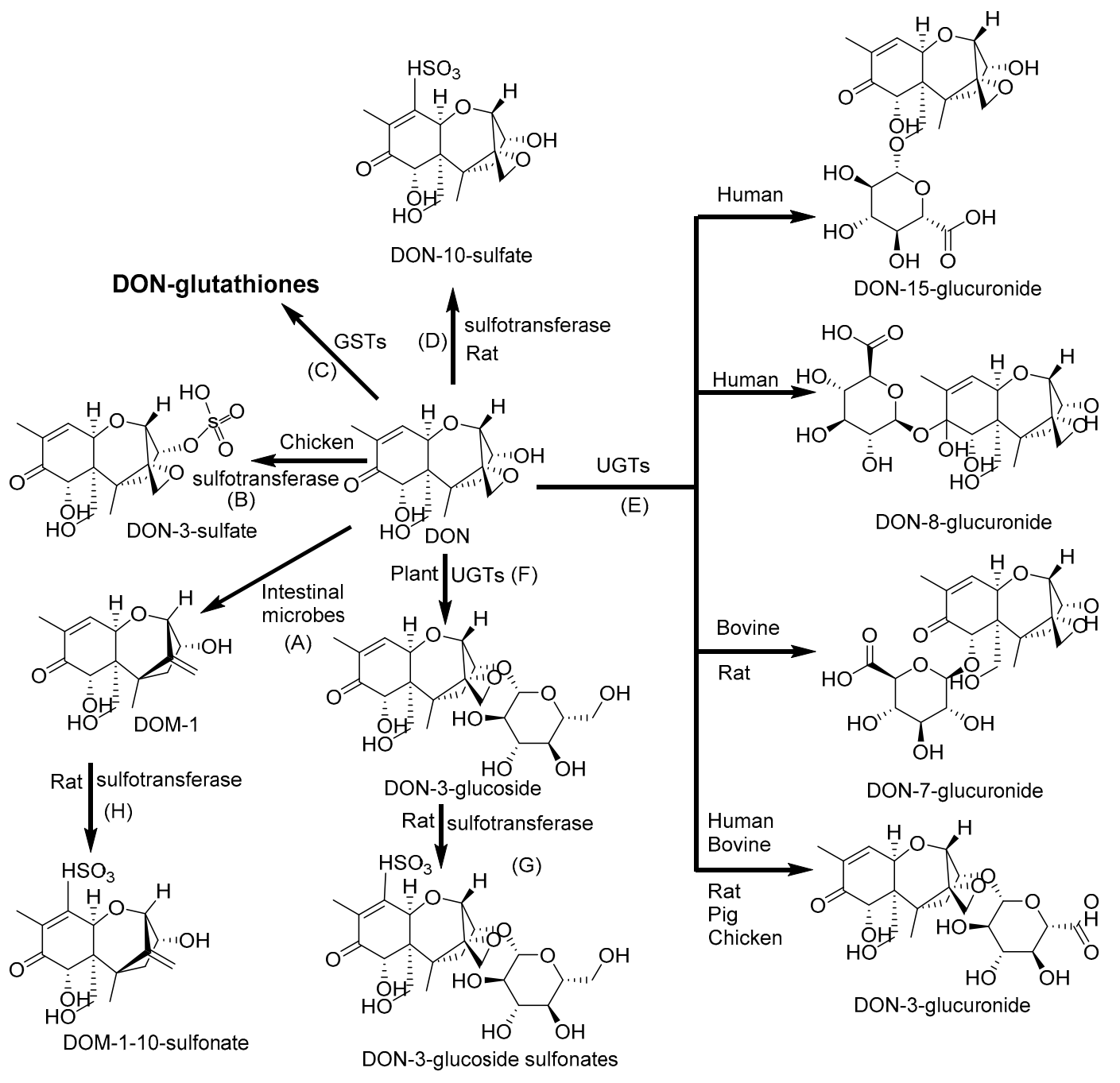

Figure 4. Phase II biotransformation of deoxynivalenol (DON): (A) Deepoxy-deoxynivalenol (DOM-1) by deepoxidation; (B) DON-3-sulfate, (D) DON-10-sulfate, (G) DON-3-glucoside sulfonate and (H) DOM-1-10-sulfonate by sulfation; (C) DON-glutathiones by conjugation with glutathione; (E) DON-3-glucuronide, DON-7-glucuronide, DON-8-glucuronide, and DON-15-glucuronide by conjugation with glucuronic acid; and (F) DON-3-glucoside by conjugation with glucose. GSTs: Glutathione S-transferases; UGTs: Uridine 5' -diphospho-glucuronosyltransferases [102].

\subsection{Biotransformation of T-2 and HT-2}

The major metabolic pathways of T-2 include hydroxylation, hydrolysis, deepoxidation, and conjugation (Figure 5) [153]. The typical metabolites of T-2 in human and animals are HT-2 toxin (HT-2), neosolaniol (NEO), 3'-OH-T-2, 3'-OH-HT-2, T-2 triol, T-2 tetraol, and some C12,13-deepoxy products [99,154]. The contributions of the CYP450 enzymes to T-2 metabolism follow the descending order of CYP3A4, CYP2E1, CYP1A2, CYP2C9, and CYP2B6 or CYP2D6 or CYP2C19, in which CYP3A4 contributes the most [93]. In addition, CYP1A1 in human [34]; CYP3A46, CYP3A29, and CYP3A22 in pig [94-96]; and CYP1A5 and CYP3A37 in chicken [97,98] mainly convert T-2 to 3'-OH-T-2 and HT-2 to $3^{\prime}-\mathrm{OH}-\mathrm{HT}-2$ [145]. The carboxylesterase is also an important phase I enzyme, contributing to the rapid metabolism of T-2 to HT-2 [100]. A recent study revealed that cholic acid supplementation promotes the T-2 metabolism through activation of the farnesoid $X$ receptor, which was found to have significantly increased the expression of CYP3A37 [99]. In phase II, glucuronidation of T-2 toxin, HT-2 toxin, and further phase I metabolites essentially contribute to the metabolism and excretion. The transformation of T-2 to T-2-3-glucuronide and HT-2 to HT-2-3-glucuronide and 
HT-2-4-glucuronide occurs in liver microsomes of rats, mice, pigs and humans [155]. The activities of GSTs and sulfotransferases can be also attributed to the conjugation reaction as a response to T-2 exposure $[100,101]$.

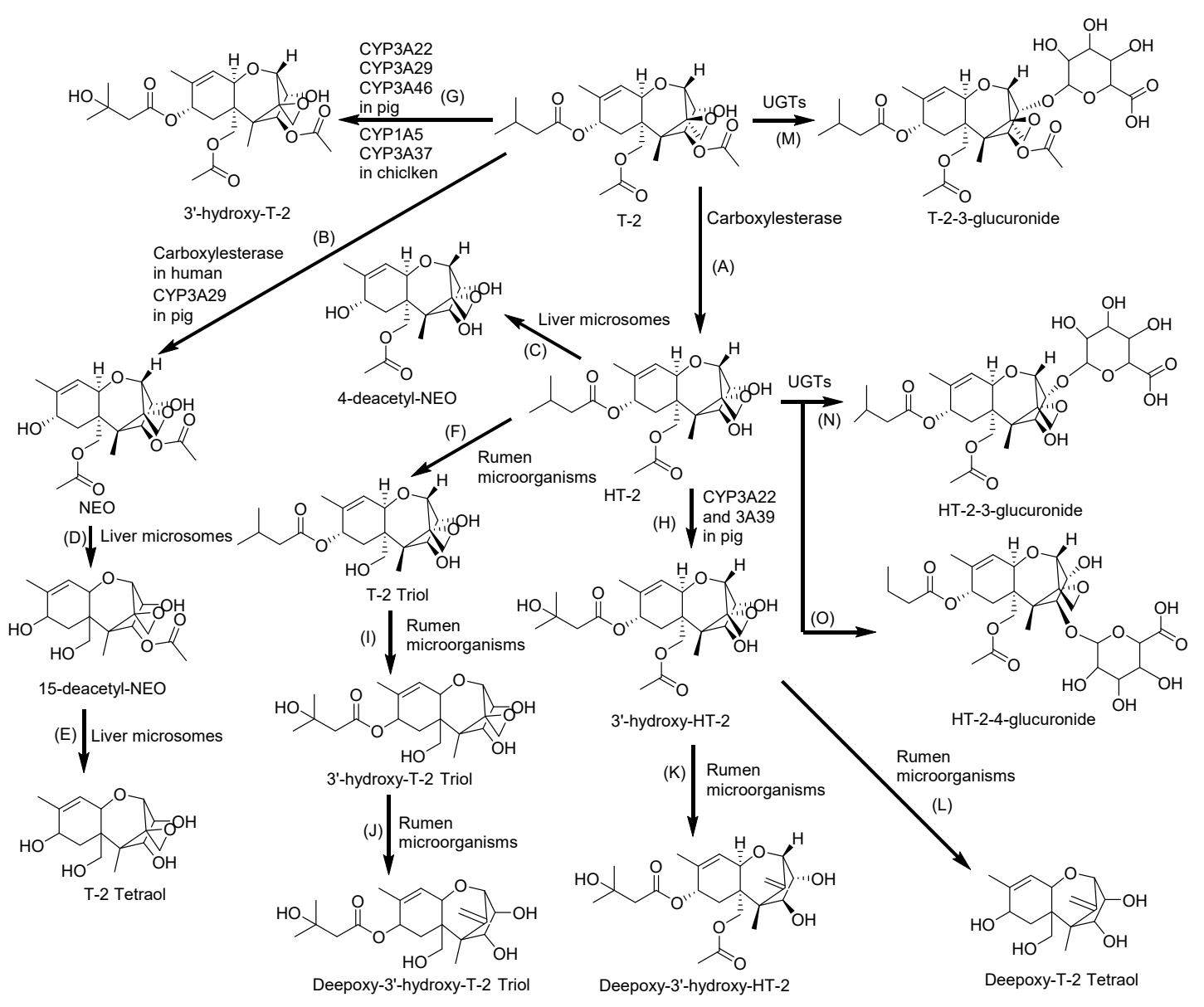

Figure 5. Metabolic pathway of T-2 toxin (T-2): (A) HT-2 toxin (HT-2), (B) Neosolaniol (NEO), (C) 4-deacetyl-NEO, (D) 15-deacetyl-NEO, (E) T-2 triol and (F) T-2 tetraol by hydrolysis; (G) 3'-hydroxy-T-2, (H) 3'-hydroxy-HT-2 and (I) 3'-hydroxy-T-2 triol by hydroxylation; (J) Deepoxy 3'-hydroxy-T-2 triol, (K) Deepoxy-3'-hydroxy-HT-2; (L) Deeopoxy-T-2 Tetraol by deepoxiadtion; and (M) T-2-3-glucuronide, (N) HT-2-3-glucuronide, and (O) HT-2-4-glucuronide by conjugation with glucuronic acid. UGTs: Uridine 5'-diphospho-glucuronosyltransferases [154].

\subsection{Biotransformation of Fumonisins}

After oral ingestion, FB1 are excreted primarily in the feces, either in the intact form or converted into aminopentol (HFB1) and partially hydrolyzed FB1 (pHFB1) by the intestinal microbiota (Figure 6) [116]. The supplementation with fumonisin carboxylesterase FumD results in the gastrointestinal degradation of FB1 and is considered as an effective strategy to detoxify FB1 in the digestive tract of turkeys and pigs [156]. The findings of Daud et al. [157] provided evidence that human fecal microbiota are capable of FB1 degradation, and LC-MS/MS fragmentation patterns indicated microbial biotransformation to hydrolyzed and partially hydrolyzed FB1 [157]. FB1 is not metabolized by CYPs. Moreover, it is a selective inhibitor of CYP2C11 and CYP1A2, while the activities of CYP2A1:2A2, CYP2B1:2B2, CYP3A1:3A2, and CYP4A are not significantly affected. The significant inhibition of CYP2C11 might be related to suppressed protein kinase activity as a result of the inhibition of sphingolipid biosynthesis caused by FB1 [158-160]. FB1, HFB1, and pHFB1 can be acetylated to form $\mathrm{N}$-acetylated fumonisins with fatty acid of various lengths, and $\mathrm{N}$-acyl forms proved to be more toxic than the parent FB1 [161-163]. 
<smiles>CCCC[C@H](C)[C@H](O)[C@@H](O)C[C@H](C)C[C@H](O)CCCC[C@H](O)C[C@H](O)[C@H](C)N</smiles>

HFB1<smiles>CCCCC(C)C(O)C(CC(C)CC(O)CCCCC(O)CC(O)C(C)N)OC(=O)CC(CC(=O)O)C(=O)O</smiles><smiles>CCCCC(C)C(CC(C)CC(O)CCCCC(O)CC(O)C(C)N)OC(=O)CC(CC(=O)O)C(=O)O</smiles>
FB1

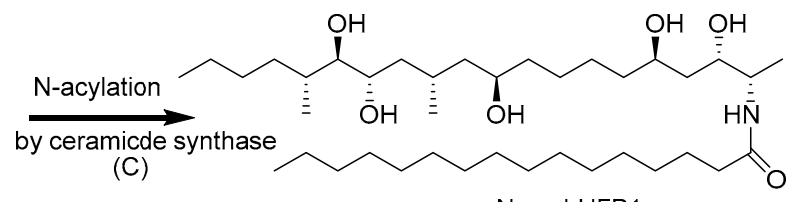

$\mathrm{N}$-acyl-HFB1
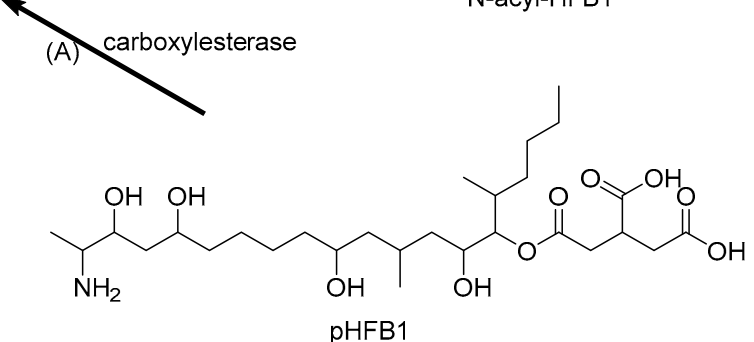

pHFB1

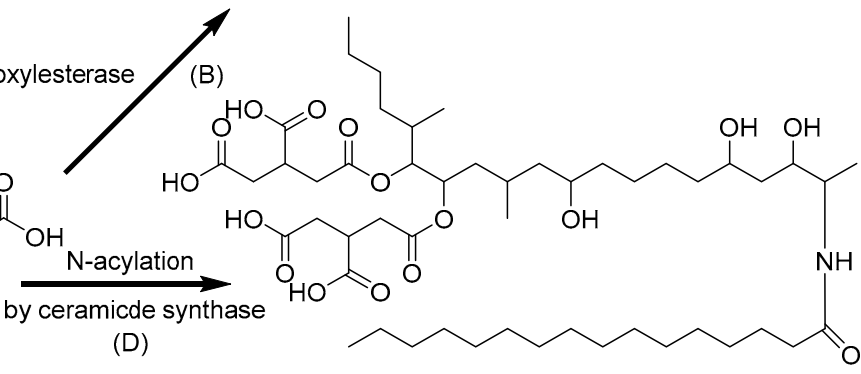

$\mathrm{N}-$ acyl-FB1

Figure 6. Metabolic pathway of fumonisin B1 (FB1): (A) Aminopentol (HFB1) and (B) partially hydrolyzed FB1 (pHFB1) by hydrolysis; (C) N-acyl-HFB1 and (D) N-acyl-FB1 by $N$-acylation [161-163].

\subsection{Biotransformation of Zearalenone}

ZEA is mainly biotransformed into $\alpha$-zearalenol ( $\alpha$-ZEA), which shows the highest binding affinity to human and porcine estrogen receptors, whereas in broilers and rats, $\beta$-zearalenol ( $\beta$-ZEA) with the low affinity to the receptor is predominantly produced [103-105]. ZEA upregulates mainly mRNA levels of CYP2B6, CYP3A4, CYP1A2 and CYP1A1, followed by CYP3A5 and CYP2C9, together with activation of their transcriptional regulators-aryl the hydrocarbon receptor (AhR), constitutive androstane receptor (CAR), and pregnane $X$ receptor (PXR) [106]. It is well known that ZEA, $\alpha$-ZEA, and $\beta$-ZEA are substrates of UGT, the enzyme responsible for the glucuronidation (Figure 7) $[78,105,164,165]$. However, the UGT was not only saturated but also inhibited by high concentration of ZEA [166]. Although zearalenone-14-glucoside (ZEA14Glc) has lower toxicity than ZEA due to inability to interact with estrogen receptors, the possible systemic hydrolysis and further activating metabolism of ZEA14Glc leads to ZEA-mediated toxicity [167]. Due to the adverse effect of ZEA on human and animal health, microorganisms have gained great interest in the modulation of ZEA adsorption and transformation $[168,169]$. Eukaryotic cells were able to biotransform ZEA to $\alpha$-ZEA and $\beta$-ZEA, while prokaryotic cells only absorbed ZEA without any metabolization of this mycotoxin and sequestered ZEA by binding to the cell wall $[170,171]$. 


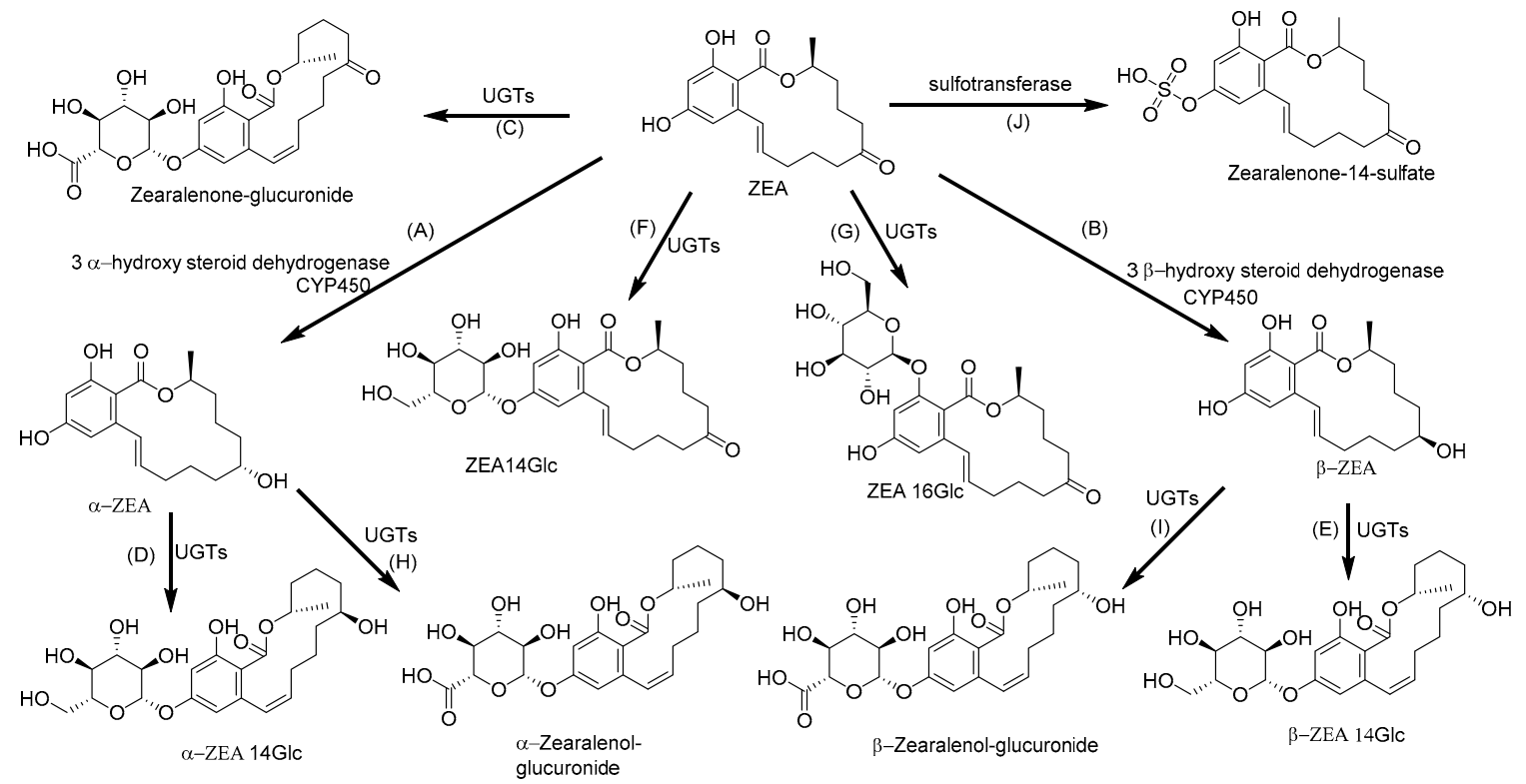

Figure 7. Metabolic pathway of zearalenone (ZEA): (A) $\alpha$-zearalenol (B) $(\alpha$-ZEA) and $\beta$-zearalenol ( $\beta$-ZEA) by hydroxylation; (C) Zearalenone-glucuronide, (D) $\alpha$-zearalenol-glucuronide and (E) $\beta$-zearalenolglucuronide by glucuronidation; (F) Zearalenone-14-glucoside (ZEA14Glc), (G) Zearalenone- 16-glucoside (ZEA16Glc), (H) $\alpha$-zearalenol-14-glycoside and (I) $\beta$-zearalenol-14-glucoside by glycosidation; and (J) Zearalenone-14-sulfate by sulfation. UGTs: Uridine 5'-diphospho-glucuronosyltransferases [170].

\subsection{Biotransformation of Enniatins}

For ENNs, the most information is currently available for ENN B and B1. In vitro and in vivo studies demonstrated that CYP3A4, CYP2C19, and CYP1A2 play the major role for ENN B metabolism in human microsomes and CYP3A and CYP1A are also included in this process in rats and dogs [109]. The 12 biotransformation products were characterized after the incubation of ENN B with rat, dog, and human liver microsomes (Figure 8): M1-M5 were monohydroxylated and M6 and M7 were $\mathrm{N}$-demethylated, whereas M8-M12 were the result of multiple oxidations [110]. However, only eight metabolites could be detected in the case of chicken liver microsomes, particularly five hydroxylated (M1-M5) and three carboxylated (M9, M11 and M12) metabolites. Moreover, M4 and M13 were major metabolites in egg samples, while M11 and M13 were found in liver and serum samples collected after broilers and hens were given contaminated feed containing ENN B [111]. Similarly, ENN B1 is mainly metabolized by CYP3A4 [112]. In vitro incubation with minipig and slaughter swine liver microsomes resulted in the detection of ten ENN B1 metabolites (M2-M11) and M1 occurred only in the minipig assays, while six metabolites (M5-M8) were detected also in vivo [113]. Rumen microbiota also proved to be able to degrade ENN B up to $72 \%$ after $48 \mathrm{~h}$ of incubation [114]. Any sulfated or glucuronidated phase II metabolites of ENN B or ENN B1 were detected (Figure 9) [115]. 

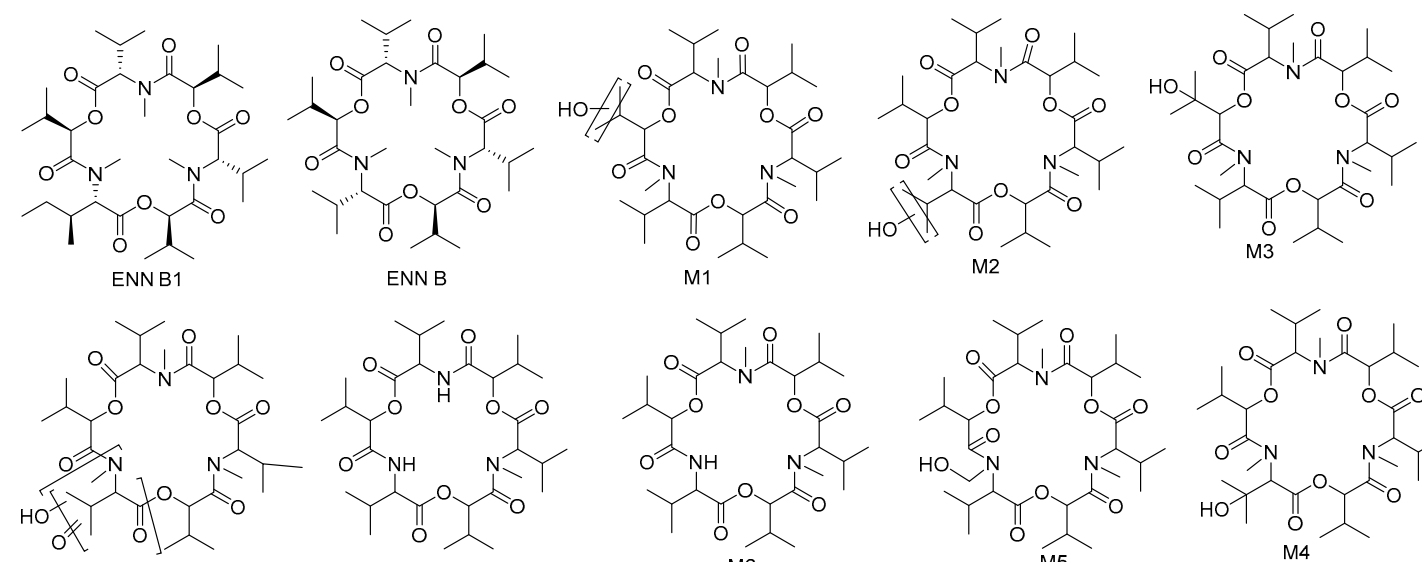

M8
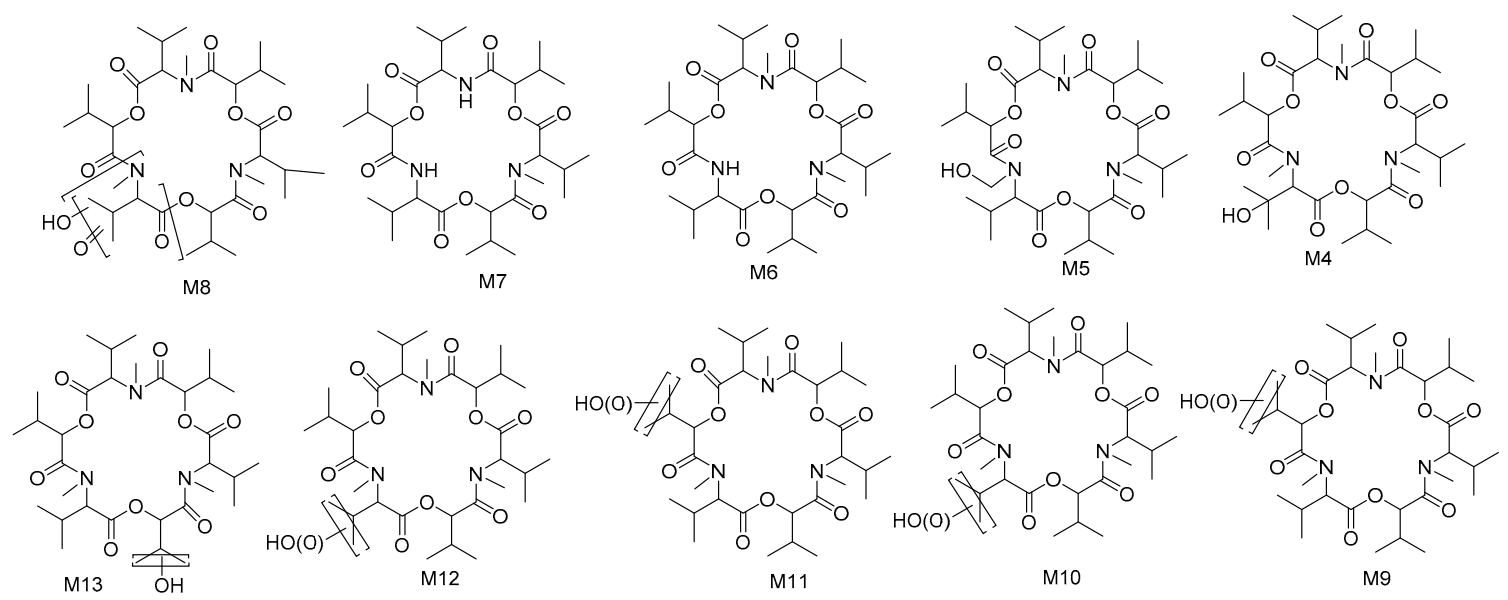

Figure 8. Molecular structures of ENN B, and B1, and proposed structures of their metabolites [110,111].

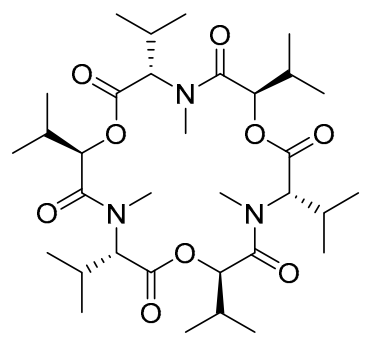

CYP1A2, 3A4 and 2C19 in human

CYP3A and CYP1A in dog and rat

Metabolites M1- M12

ENN B

Figure 9. The biotransformation of ENN B [110,111].

\subsection{Biotransformation of Beauvericin}

Very few studies have been carried out on BEA (Figure 10) in this regard. No BEA metabolites were detected in the mice feed with BEA in the study of Rodríguez-Carrasco et al. [107], suggesting a higher metabolic stability for BEA [107]. Mei et al. [108] reported that BEA is a potent inhibitor of diverse CYP450 enzymes, including CYP3A4/5 and CYP2C19 in human liver microsomes and CYP3A1/2 in rat liver microsomes [108].

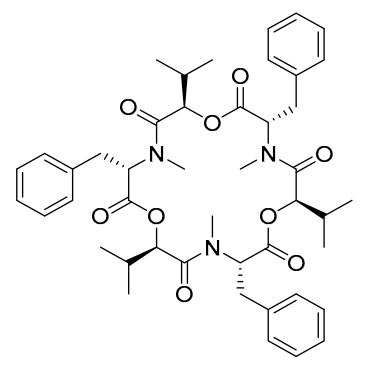

Figure 10. Molecular structure of BEA. 


\subsection{Biotransformation of Alternaria Mycotoxins}

$\mathrm{AOH}$ and AME form the metabolites hydroxylated at C-2, C-4, and C-8 by activation of the CYP1A1 enzyme (Figure 11) [172,173]. AOH and AME activate the AhR pathway, which induces CYP1A1 expression [117,118]. AOH is known for its genotoxicity [118]. However, the phase I metabolites, 4-OH-AOH and 4-OH-AME, had minor effect compared to AOH or AME in topoisomerase inhibition and DNA strand-breaking effects [174]. Phase II metabolism includes conjugation with glucuronic acid and sulfate [119]. AME and AOH were enzymatically glycosylated using whole-cell biotransformation system, producing highly effective rates of 58\% AOH-3-glucoside, 5\% AOH-9-glucoside, and 24\% AME-3-glucoside [120]. However, human gut microbiota was not capable of metabolizing AOH, AME, and ALT [175]. The conversion of ATX-II, significantly more genotoxic than AOH, to ATX-I by de-epoxidation in Caco-2 cells did not showed an adequate detoxification but an attenuation of genotoxicity [176]. The metabolic pathway of $\mathrm{AOH}, \mathrm{AME}$ and other Alternaria mycotoxins, such as TEN, TeA, ALT and ATXs, are summarized in Figure 11.

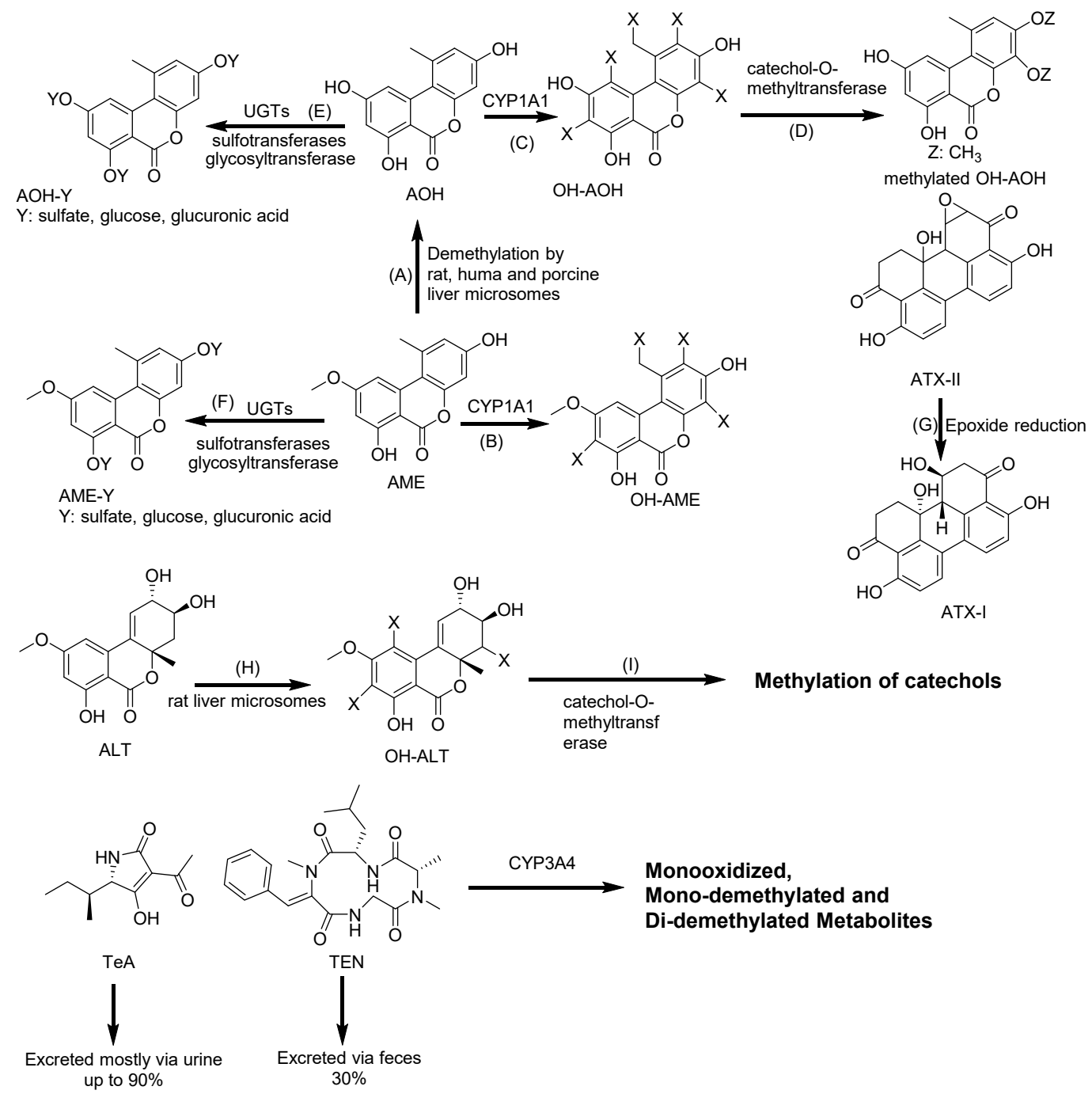

Figure 11. Biotransformation pathway of Alternaria mycotoxins: Alternariol (AOH), alternariol monomethyl ether (AME), hydroxy-alternariol $(\mathrm{OH}-\mathrm{AOH})$, hydroxy-alternariol monomethyl ether (OH-AME), tenuazonic acid (TeA), altertoxins (ATXs), Tentoxin (TEN), altenuene (ALT), hydroxylaltenuene (OH-ALT). (A): Demethylation; (B,C,H): Hydroxylation; (D,I): Methylation; (E,F): Sulfation, glycosylation, and glucuronidation; (G): Epoxide reduction. CYP: Cytochrome P; and UGTs: Uridine 5'-diphospho-glucuronosyltransferase [71,117,121,172-174,177-181]. 


\subsection{Biotransformation of Patulin}

PAT induces the upregulation of PXR and AhR accompanied by the enhancement of CYP1A1, CYP1A2, CYP2B6, CYP2C9, CYP 3A4, and CYP3A5 expression [130]. Moreover, PAT reacts with intracellular glutathione in gastrointestinal mucosa cells [182,183]. The extracellular enzymes of Lactobacillus casei YZU01 induced by PAT mainly degrades PAT, and the cell wall of this bacteria can also absorb a small amount of PAT [184]. Similarly, the degradation of PAT was observed by Saccharomyces cerevisiae during cider fermentation into E-ascladiol and Z-ascladiol (Figure 12), which are not toxic to human [185]. The biotransformation of PAT in humans and animals is not well understood and remains to be established.

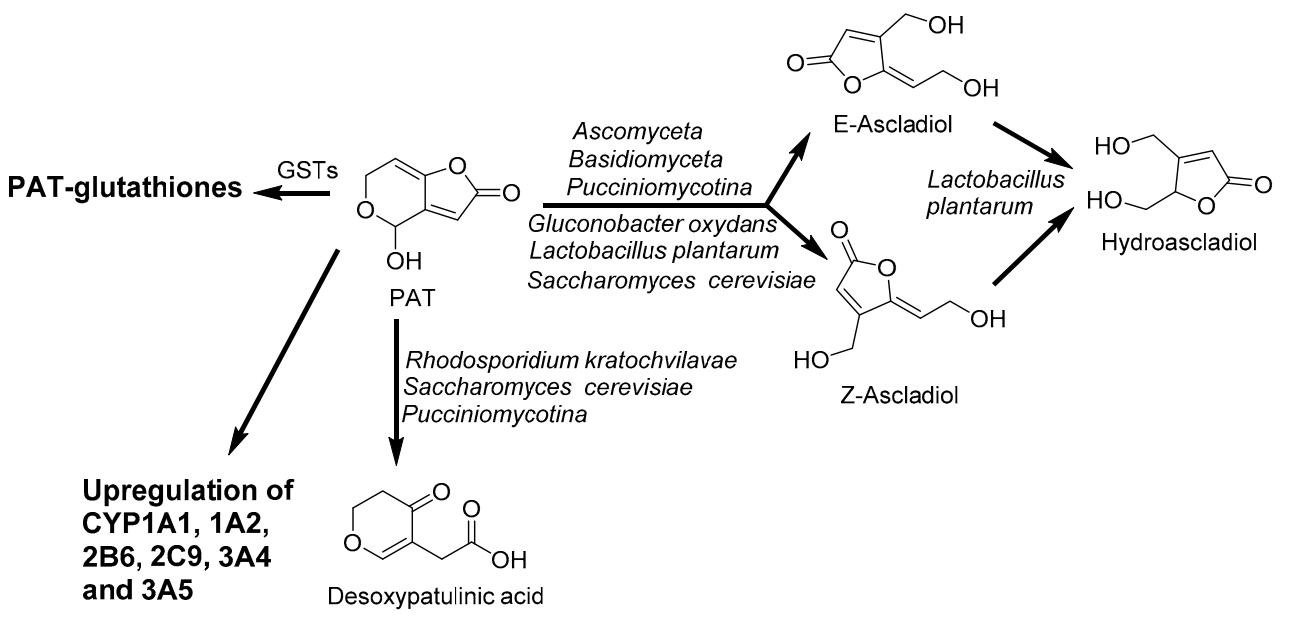

Figure 12. Biotransformation pathway of patulin (PAT): E-ascladiol, Z-ascladiol, hydroascladiol, and desoxypatulinic acid by microorganism, and PAT-glutathiones by reaction with glutathione. GSTs: Glutathione S-transferase [130,182,183,185,186].

\section{Assessment of Bioavailability of Mycotoxins Using Caco-2 Cell Monolayer}

The Caco-2 cell line is the most common and extensively used in vitro model to study the intestinal absorption of mycotoxins via the intestinal membrane enterocytes $[2,10,187,188]$. It was originally derived from a heterogeneous human epithelial colorectal adenocarcinoma cells established by Fogh and coworkers in 1977 [189]. The Caco-2 cells have the ability to spontaneously differentiate into a monolayer of cells, expressing many properties typical of absorptive enterocytes with a brush border layer, tight junctions, and efflux and uptake transporters as found in the small intestine [190-192]. Moreover, several phenolic compounds (e.g., kaempferol) are able to regulate the MAPK pathway, which is beneficial to the barrier functions [193]. Kaempferol treatment showed significant an increase in claudin 3, claudin 4, and occluden [194]. On the other hand, several mycotoxins-deoxynivalenol, zearalenone, fumonisin B1, T-2 toxin, aflatoxin M1, and ochratoxin A-have a deleterious effect on tight junctions of claudin 3, claudin 4, claudin 7, and occluden [195-198].

The Caco-2 cells have been shown to be a suitable model for biotransformation study because they express various phase-I hydroxylation and phase-II conjugation enzymes, and transport proteins of the ATP-Binding Cassette (ABC) superfamily [166]. Furthermore, a good correlation has been found for data on oral absorption in humans and the results in the Caco-2 model [199].

To closer mimic the intestinal barrier in vivo, Caco-2 cells were seeded on permeable membranes to form a confluent monolayer with a well-defined tight junction for approximately 21 days post-seeding [78]. The integrity of the Caco-2 monolayer was monitored by measuring the transepithelial electrical resistance (TEER), or by examining the permeability of paracellular markers, such as mannitol, inulin, Dextran, PEG 4000, Lucifer yellow, and phenol red [191,200]. Studies that have investigated the bioavailability of mycotoxins by Caco-2 cells are listed in Table 6. The results of these studies show that mycotoxins are transported through Caco-2 monolayer in different efficiencies. 
Table 6. Studies investigating bioavailability of mycotoxins by Caco-2 cells.

\begin{tabular}{|c|c|c|c|c|}
\hline Mycotoxins & Concentration $(\mu \mathrm{M})$ & Incubation Time (h) & Major Findings & References \\
\hline $\mathrm{AOH}$ and $\mathrm{AME}$ & 20 & $1-3$ & $\begin{array}{l}\text { 22.7-25.8\% and 3-7.1\% applied AOH and AME reached the basolateral } \\
\text { compartment (including their metabolites). }\end{array}$ & [119] \\
\hline ATXs & 10 & 0.5 & $\begin{array}{l}6 \% \text { and } 0.3 \% \text { applied ATX I and ATX II found in basolateral compartment. } \\
\text { ATX I were not metabolized. } \\
13 \text { and } 4 \% \text { metabolites of ATX II found in apical and basolateral compartments. }\end{array}$ & {$[201]$} \\
\hline AFB1 & $1-25$ & $24-48$ & $\begin{array}{l}\text { CYP1A2 and 3A4 were the main CYP450 isoforms for AFB1 activation into the } \\
\text { genotoxic metabolite aflatoxin-exo-7-8-epoxyde. }\end{array}$ & [9] \\
\hline AFB1, FB1, OTA and T-2 & 100 & 24 & AFB1, FB1, T2 and OTA disrupted the intestinal barrier permeability. & [198] \\
\hline BEA & $1.5-3$ & 4 & Bioavailability was from $50.1-54.3$ for BEA & \\
\hline DON & $5-30$ & 24 & $\begin{array}{l}\text { DON transcellular passage was either by passive/facilitated diffusion or by } \\
\text { active transport. } \\
\text { DON was a substrate for both P-gp and MRP2. }\end{array}$ & [202] \\
\hline ENNs & $1.5-3$ & $\begin{array}{c}4 \\
48\end{array}$ & $\begin{array}{l}\text { Duodenal bioavailability: } 57.7-76.8 \% \text { for ENN A, } 68.8-70.2 \% \text { for ENN A1, } \\
65.0-67.0 \% \text { for ENN B, and } 62.2-65.1 \% \text { for ENN B1. } \\
\text { Colonic bioavailability: } 17.3-33.3 \% \text { for ENN A, } 40.8-50.0 \% \text { for ENN A1, } \\
47.7-55.0 \% \text { for ENN B, and } 52.4-57.4 \% \text { for ENN B1 }\end{array}$ & [67] \\
\hline MPA & $0-780$ & - & Decrease in the barrier function of Caco-2 cell monolayer. & [9] \\
\hline OTA & $\begin{array}{l}1-100 \\
5-45\end{array}$ & $\begin{array}{c}1 \\
3-24\end{array}$ & $\begin{array}{l}\text { OTA was a substrate for MRP2 and BCRP } \\
\text { Metabolites were OTB, OTA methyl ester, OTA ethyl } \\
\text { ester and the OTA glutathione conjugate. }\end{array}$ & $\begin{array}{l}{[204]} \\
{[205]}\end{array}$ \\
\hline ZEA & 25 & 4 & $\begin{array}{c}\text { ZEA was substrates for } \mathrm{ABCC} 1, \mathrm{ABCC} 2 \text { and metabolites into } \alpha \text { - and } \\
\beta \text {-zearalenol and glucuronides. }\end{array}$ & [206] \\
\hline
\end{tabular}


DON, NIV, ZEA ENNs, and BEA cross easily the cell barrier. DON is efficiently transported through the intestinal barrier possibly either by passive/facilitated diffusion [202] or by paracellular passage through intercellular tight junctions [207]. All of the apparent permeability $\left(\mathrm{P}_{\text {app }}\right)$ values greater than $1 \times 10^{-6} \mathrm{~cm} / \mathrm{s}$ suggest that these mycotoxins were absorbed efficiently [208]. $P_{\text {app }}$ values for DON have been reported by many researchers. Sergent et al. [207] reported an average $P_{a p p}$ value of $5.02 \times 10^{-6} \mathrm{~cm} / \mathrm{s}$ for absorption (apical (AP)-basolateral (BL) compartment) and excretion (BL-AP direction) [207]. In other study, absorption and excretion $P_{\text {app }}$ values ranged 1.23-2.06 $\times 10^{-6}$ and 2.68-2.8 $\times 10^{-6} \mathrm{~cm} / \mathrm{s}$, respectively [202]. Finally, $P_{\text {app }}$ value of $3.3 \times 10^{-6}$ and $2.8 \times 10^{-6} \mathrm{~cm} / \mathrm{s}$ for absorption and excretion, respectively, were determined in study of Kodota et al. [209]. A faster bidirectional transport of DON in the mixture comparing to pure DON was observed, suggesting that the presence of other mycotoxins including AFB1, FB1, and OTA may promote intestinal transport of DON [210]. For NIV, transcellular transport probably occurred by passive diffusion in the absorptive direction, and $P_{\text {app }}$ values were also higher than $10^{-6} \mathrm{~cm} / \mathrm{s}$ [203]. The $P_{\text {app }}$ values obtained with a concentration of $20 \mu \mathrm{M}$ ZEA in the apical compartment and an incubation time of $1 \mathrm{~h}$ were $10.47 \pm 4.7 \times 10^{-6} \mathrm{~cm} / \mathrm{s}$ [211]. About $30 \%$ of initial ZEA crossed the cell monolayer after $3 \mathrm{~h}$ of exposure, and $40 \%$ of ZEA was absorbed by the intestinal after $8 \mathrm{~h}$ [78]. ZEA presented higher bioavailability than its metabolites, $\alpha$-ZEA, ranging from $10 \%$ to $36 \%(0-4 \mathrm{~h} ; 30 \mu \mathrm{M})$ [72]. Unlike DON-3-glucoside (neither absorbed or cleaved by Caco-2 cells), ZEA-14Glc and ZEA-16Glc could cross the cell barrier and be absorbed by Caco- 2 cells, resulting in further cleavage and the subsequent release of their parent deglycosylated forms [212]. BEA bioavailability was variable from $50 \%$ to $54 \%$ [213]. Higher duodenal bioavailability compared to colonic bioavailability of ENNs was observed. Particularly, the duodenal bioavailability of ENNs ranged from $58 \%$ to $77 \%$ for ENN A, from $69 \%$ to $70 \%$ for ENN A1, from $65 \%$ to $67 \%$ for ENN B, and from $62 \%$ to $65 \%$ for ENN B1. Colonic bioavailability ranged from $17 \%$ to $33 \%$ for ENN A, from $41 \%$ to $50 \%$ for ENN A1, from $48 \%$ to $55 \%$ for ENN B, and from $52 \%$ to $57 \%$ for ENN B1 [67]. In contrast, FB1 was not absorbed by Caco-2 cells [214].

Berger et al. [215] showed that OTA was absorbed by the human intestinal mucosa by passive diffusion of the undissociated form of OTA and it was not appreciably metabolized by Caco-2 cells [215]. DON and NIV were not significantly metabolized or accumulated in Caco-2 cells as well $[71,202,203,207,216,217]$. Therefore, upon ingestion, these mycotoxins can be absorbed from the gut via intestine cells, then entered into the systemic circulation and thus transported to the whole body. Nevertheless, the intestinal absorption of OTA would be limited thanks to the presence of the MRP2 [215] and breast cancer resistance protein (BCRP) [204]. An efflux of AFB1 was also associated with BCRP [218], and DON was a substrate for both P-gp and MRP2 [202]. P-gp has been shown to be involved in the efflux of FB1 [214], and NIV interacted with P-gp and MRP2 [203]. Several studies showed that DON transport was unaffected by the transporter $[207,209]$. However, DON uptake and efflux are carrier-mediated processes, and P-gp and organic anion-transporting peptides may be the major efflux/uptake transporters for DON in Caco-2 cells, respectively [219]. The stepwise c-Jun- $N$-terminal kinase-Akt-nuclear factor kappa-light-chain-enhancer of activated $B$ cells (JNK-Akt-NF-kB) pathway elaborates upon P-gp induction following DON exposure in mammalian cells and provides a self-protection mechanism to resist exogenous toxic compounds such as DON and T-2 [220]. These dissimilarities may be consequences of differences in exposure conditions to the toxin. Particularly, transport experiments were performed in $\mathrm{pH}$ gradient, and the acidification of the apical compartment may increase the fraction of the uncharged molecules facilitating diffusion across the cell membrane and intracellular accumulation [221]. Furthermore, differences in the culture medium, passage number, and time in culture before splitting may lead to significant differences in $\mathrm{ABC}$ transporter expression and functionality [222].

Intestinal absorption of $\mathrm{AOH}$ was more extensive and faster than AME. About 23-26\% of the apically applied $\mathrm{AOH}$ reached the basolateral compartment, while only about $3-7 \%$ of the initial amount of AME in the apical chamber reached the basolateral side. In basolateral medium, several metabolites were also detected: Three $\mathrm{AOH}$ metabolites (3-O-sulfate, 3-, and 9-O-glucuronide) 
and AME-3-O-glucuronide [119]. Several authors have already shown the ability of Caco-2 cells to metabolize ZEA into $\alpha$ - or $\beta$-ZEA, as well as into its glucuronidated and sulphated forms $[78,166,211]$. Videmann et al. [206] established that facilitated or active transport was involved in the transportation of ZEA and its metabolites. Particularly, they were substrates for ABCC1-3 transporters. ZEA and $\alpha$-ZEA were mostly extruded by ABCC2 at the AP side and ABCC3 was able to transport $\beta$-ZEA at the BL side [206].

Treatment of Caco-2 cells with mycotoxins at reasonable concentrations must have no significant effect on cell viability, cell damage, and barrier integrity. FB1 at a concentration of up to $138 \mu \mathrm{M}$ did not induce variation on cell viability and differentiation [214]. Similarly, ZEA concentration of up to $200 \mu \mathrm{M}$ had no significant effect on cell viability and cell damage $[78,206]$, and the integrity of the cell monolayers was preserved throughout the incubation with ZEA at a concentration of up to $40 \mu \mathrm{M}$, indicating that ZEA does not have detrimental effects on epithelial integrity in vitro [212]. Moreover, Caco-2 cells exposure to $5 \mu \mathrm{M}$ of NIV showed neither a significant increase in the sucrose flux nor a significant decrease in TEER values [203]. DON also had no significant effect on Caco-2 cell viability at a concentration of up to $33 \mu \mathrm{M}[202,209]$.

However, other studies reported that mycotoxins such as ZEA, DON, FB1, T-2, PAT, AFB1, and OTA decreased the TEER of intestinal epithelial cell lines in porcine as well as in human epithelium [10,195,196,198,223-227]. A reduction in TEER can cause an increase in the paracellular permeability, changes in transcellular flux through altered plasma channels or pumps, and uncontrolled cell death within the monolayer [228]. Pfeiffer et al. [211] showed that $20 \mu \mathrm{M}$ of ZEN was able to affect the apparent permeability coefficients of Caco-2 cells, leading to their quick absorption from the intestinal lumen into the portal blood [211]. Moreover, the important indicators of intestinal permeability are tight junction proteins, which are comprised of several multiprotein complexes, including transmembrane proteins (claudin, occludin, and junctional adhesion molecule) and cytoplasmic scaffolding protein and signaling proteins, including zonula occludens [229]. DON, ZEA, FB1, T-2, AFM1, and OTA have a deleterious effect on tight junctions of claudin 3, claudin 4, claudin 7, and occluden [195-198].

Tight junction structure and function can be regulated by signaling molecules involved in the mitogen-activated protein kinase-dependent (MAPK) pathways [230]. Therefore, the rapid activation of MAPK, ZEA, and DON decreased the expression of tight junction proteins, resulting in intestinal barrier impairments [134,197]. DON and other trichothecenes are known for their binding of the ribosomal peptidyltransferase, inhibition of protein synthesis, and rapid activation of MAPK via inducing two signal transduction pathways of a process named the ribotoxic stress response [227,231-233]. The first pathway consists of the double-stranded RNA-activated protein kinase, leading to stimulation of JNK and p38 [25]. The second pathway involves hematopoietic cell kinase belonging to the Src tyrosine kinase family, which are upstream transducers of activation of MAPK. Among the primary MAPK subfamilies, such as p44/42 extracellular signal-regulated protein kinase (ERK), p38, and JNK [234], p44/42 ERK can be involved in intestinal epithelial cell morphology and in the structure of tight junctions. It was reported that the DON-induced activation of the p44/42 ERK signaling pathway inhibits the expression of claudin-4, which leads to reduces the barrier function of the intestine evaluated by TEER, paracellular permeability [197,227]. Treatment with $10 \mu \mathrm{M}$ of DON also increased ERK, P38, JNK, and c-Jun phosphorylation levels by 2-fold, 30-fold, 61-fold, and 5-fold, respectively, and altered the gene expression levels of occludin, claudin-3, and the composition of tight junction proteins (Figure 13) [235]. The activation of p44/42 MAPK was partially involved in the detrimental effects of the integrity of tight junction caused by AFM1 and OTA [224]. 


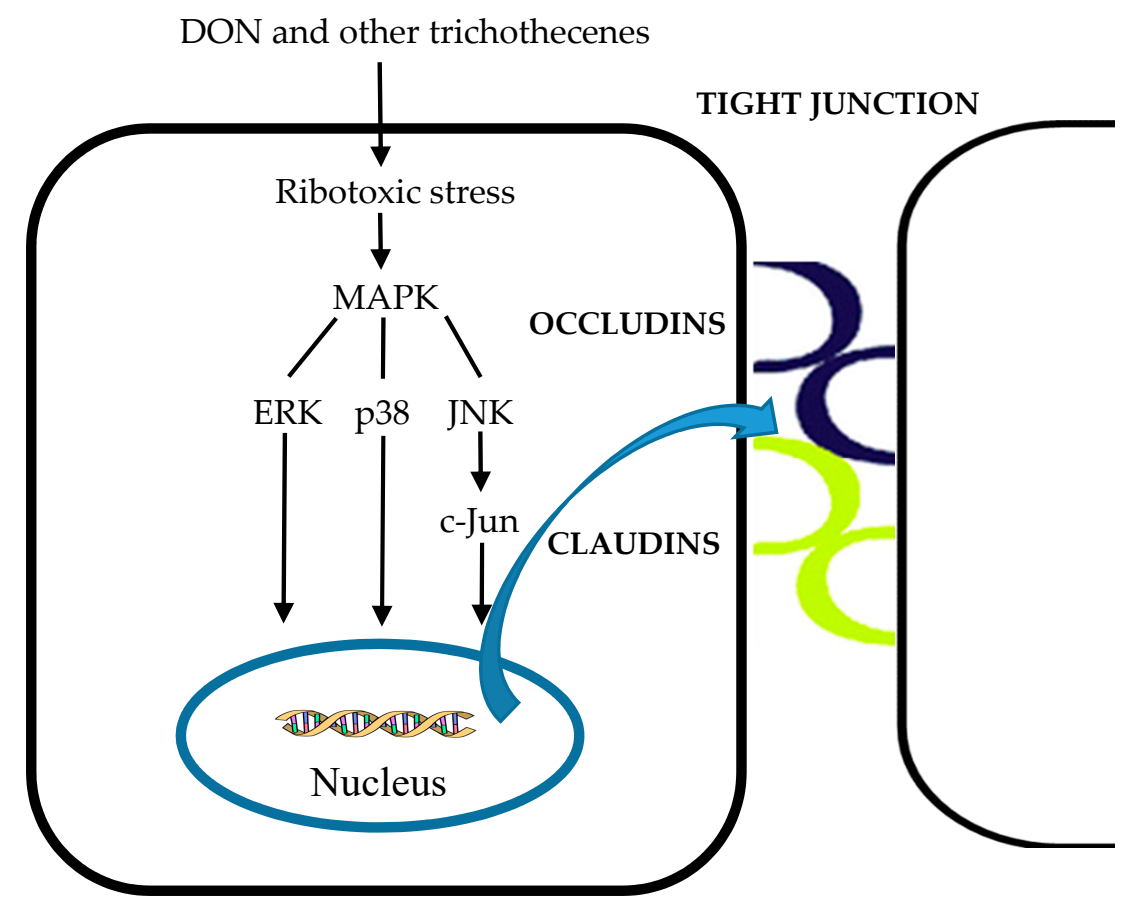

Figure 13. The effects of DON and other trichothecenes on the tight junction through activation of the MAPK pathway. MAPK: Mitogen-activated protein kinase-dependent, ERK: Extracellular signal regulated protein kinase, JNK: C-Jun- $\mathrm{N}$-terminal kinase. The colored curves represent junction proteins.

In addition to the tight junction, the maintenance of intestinal barrier-related paracellular secretions, such as cytokines and chemokines, are important as well. ZEA metabolites, $\alpha$ - and $\beta$-ZEA, can be beneficial to the intestine by decreasing the expression of both interleukin- 8 (IL-8) and interleukin-10 in a dose-dependent manner. Its metabolites have a rather anti-inflammatory effect on the epithelial intestinal cells [225]. However, cytokines are related to the impairment of intestinal integrity when exposed to ZEA and FB1 [225,226,236]. Moreover, the correlation between permeability and IL-8 secretion induced by DON in the intestine was investigated by the authors of [209]. IL-8 was examined as a factor affecting intestinal barrier function, and the increased IL- 8 secretion may be involved in the TEER decrease [237]. Similar results were reported by the authors of [238]. Consequently, exposure to certain mycotoxins, particularly DON, may cause damage to the intestinal integrity and lead to various chronic intestinal inflammatory diseases, such as inflammatory bowel disease [195]. In addition, the synergic effects of OTA and AFM1 that might exacerbate intestinal inflammation were also reported [239].

Although the Caco-2 cells model offers several advantages, such as the reproducibility of results, controlled environment, and in-depth mechanistic insight [240], some limits of Caco-2 for assessing the bioavailability were also reported [241]. The main disadvantages of these models are the lack of the regulatory processes of the complex mucosal barrier and inability to accurately calculate the fractional transport and flux rate through the static transport conditions [242]. Moreover, it has been shown that significant variation of the expression level of efflux transporters, such as BCRP, MRP2, and MDR1 in the Caco-2 cell monolayer in human small and large intestines, affect the results as well $[243,244]$. The Caco-2 cell monolayer is somewhat unsuccessful in simulating in vivo intestinal environment due to lack of expression of CYP3A4, which is responsible for the biotransformation of many compounds in the human epithelial cell [245]. Further drawbacks of these models include the incapability of simulating the changes of intestinal $\mathrm{pH}$ system, since it is performed at constant $\mathrm{pH}$ conditions. In addition, variations in TEER and permeability were also reported to be related to the source of Caco-2 cell and interlaboratory differences in protocol design [192]. 
To reduce the heterogeneity of the Caco- 2 parental cell line and to improve the performance and the stability of this cellular model, some clonal derivative of Caco-2 cells have been established. The Caco-2/TC7 cell line, which was isolated from a late passage of the parental Caco-2 line, is suitable for intestinal absorption model due to a less heterogenic cellular population, resulting in better reproducibility of results [246]. The human intestinal HT-29 cell line is another cell line from colorectal origin with epithelial morphology and has a large proportion of mature goblet cells that can produce mucins. Therefore, the co-culture of Caco-2 and HT-29 with a ratio of 9:1 was used to provide a better representation of the intestinal tract [247]. In addition, the human colon carcinoma (HCT-116) and human colon adenocarcinoma (SW480) cells used in unraveling cancer-related mechanisms and the human duodenum adenocarcinoma (HuTu-80) cell line simulating duodenal cells are less popular [191]. More recently, a combination of in vitro digestion and Caco-2 absorption was used to simulate the physiological settings in the gastrointestinal tract and determine the bioaccessibility and bioavailability of the ZEA reaction products [72].

\section{Conclusions}

Scientific insights in the production of mycotoxins, their toxicities, biotransformation, and metabolism in different organisms have greatly contributed to a more detailed understanding of the chemical hazards in food. Mycotoxins can notably biotransform and detoxify in the liver, as well as in the digestive tract. The results obtained with Caco- 2 monolayer are useful in the prediction of mycotoxins' intestinal permeability, transport mechanism, and gene regulation of transporters and enzymes in humans, and may help interpret properly data of mycotoxins' absorption for better comprehension of their possible adverse effects. Furthermore, the combined usage of in vitro digestion models with in vitro intestinal absorption models using Caco-2 cells may offer more complete picture during digestion in the intestinal tract. However, the correlation between in vitro Caco-2 data and in vivo situation necessitates further investigation.

Funding: The financial support of the mobility project from the Czech Ministry of Education, Youth and Sports INTER-COST LTC20015 (COST Action CA18111) is gratefully acknowledged. The work was also supported by the Czech National Program of Sustainability NPU I (LO1601, MSMT-43760/2015).

Conflicts of Interest: The authors declare no conflict of interest. The funders had no role in the design of the study; in the collection, analyses, or interpretation of data; in the writing of the manuscript, or in the decision to publish the results.

\begin{tabular}{ll}
\multicolumn{2}{l}{ Abbreviations } \\
3'-OH-HT-2 & $3^{\prime}$-hydroxy-HT-2 \\
3'-OH-T-2 & $3^{\prime}$-hydroxy-T-2 \\
4-OH-OTA & 4-hydroxy-ochratoxin A \\
10-OH-OTA & 10-hydroxy-ochratoxin A \\
$\alpha$-ZEA & $\alpha$-zearalenone \\
$\beta$-ZEA & $\beta$-zearalenone \\
ABC & ATP-binding cassette \\
AFB1 & aflatoxin B1 \\
AFB2 & aflatoxin B2 \\
AFBO & Aflatoxin B1-8,9-epoxide \\
AFBO-GSH & Aflatoxin B1-8,9-epoxide-glutathiones \\
AFG1 & aflatoxin G1 \\
AFG2 & aflatoxin G2 \\
AFL & aflatoxicol \\
AFM1 & aflatoxin M1 \\
AFM2 & aflatoxin M2
\end{tabular}




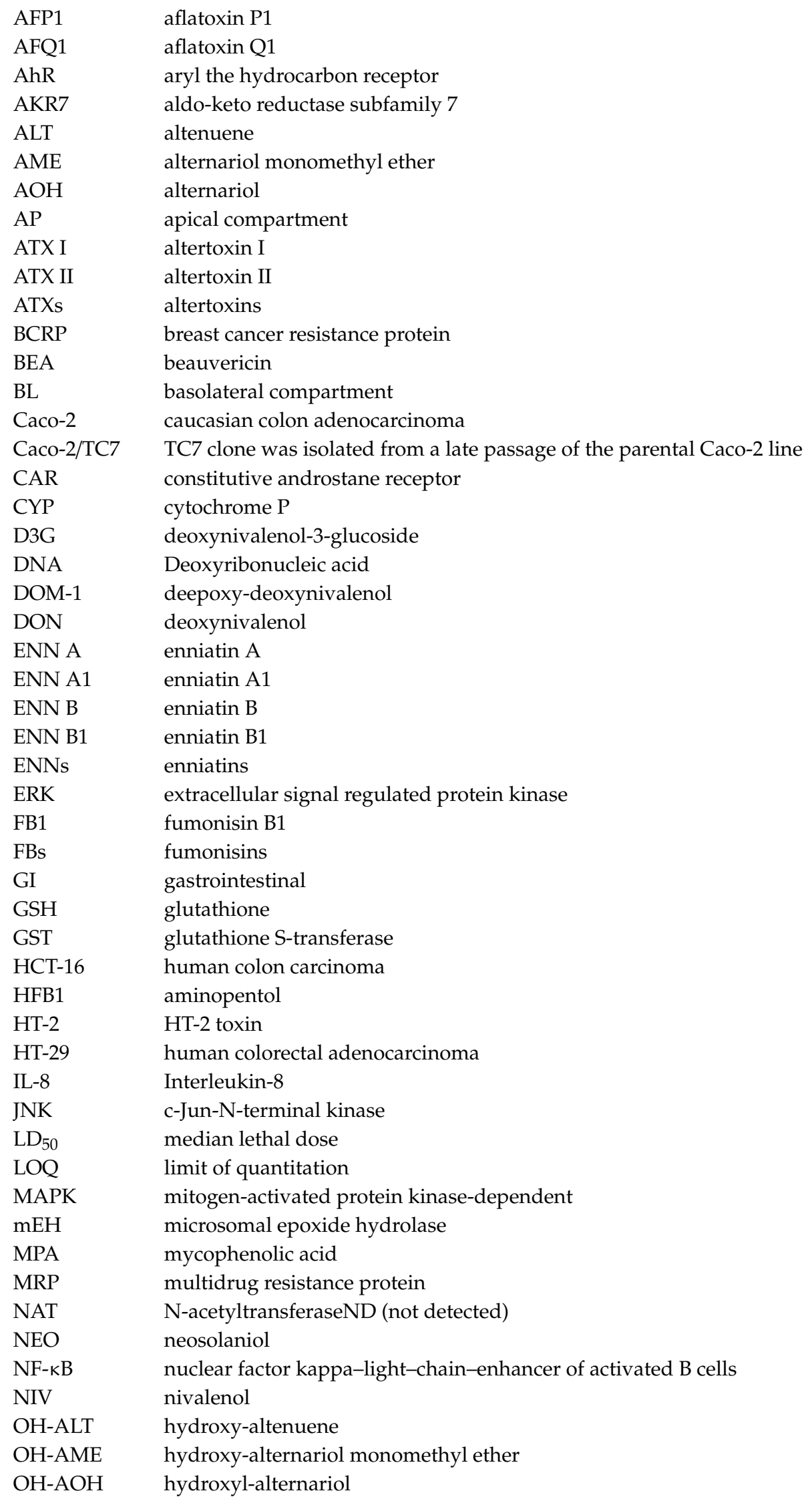




\begin{tabular}{|c|c|}
\hline OT $\alpha$ & ochratoxin $\alpha$ \\
\hline OTA & ochratoxin A \\
\hline OTB & ochratoxin B \\
\hline$P_{\text {app }}$ & apparent permeability \\
\hline P-gp & P-glycoprotein \\
\hline PAT & patulin \\
\hline pHFB1 & partially hydrolyzed fumonisin B1 \\
\hline PXR & pregnane $X$ receptor \\
\hline RNA & Ribonucleic acid \\
\hline ROS & reactive oxygen species \\
\hline SULT & sulfotransferase \\
\hline SW480 & human colon adenocarcinoma \\
\hline $\mathrm{T}-2$ & $\mathrm{~T}-2$ toxin \\
\hline $\mathrm{TeA}$ & tenuazonic acid \\
\hline TEER & transepithelial electrical resistance \\
\hline TEN & tentoxin \\
\hline UGT: & uridine $5^{\prime}$-diphospho-glucuronosyltransferase \\
\hline ZEA & zearalenone \\
\hline ZEA14Glc & zearalenone-14-glucoside \\
\hline ZEA16Glc & zearalenone-16-glucoside \\
\hline
\end{tabular}

\section{References}

1. De Boevre, M.; Graniczkowska, K.; Saeger, S. De Metabolism of modified mycotoxins studied through in vitro and in vivo models: An overview. Toxicol. Lett. 2015, 233, 24-28. [CrossRef] [PubMed]

2. Smith, M.C.; Gheux, A.; Coton, M.; Madec, S.; Hymery, N.; Coton, E. In vitro co-culture models to evaluate acute cytotoxicity of individual and combined mycotoxin exposures on Caco-2, THP-1 and HepaRG human cell lines. Chem. Biol. Interact. 2018, 281, 51-59. [CrossRef] [PubMed]

3. Kebede, H.; Liu, X.; Jin, J.; Xing, F. Current status of major mycotoxins contamination in food and feed in Africa. Food Control 2020, 110, 106975. [CrossRef]

4. Fernández-Blanco, C.; Elmo, L.; Waldner, T.; Ruiz, M.J. Cytotoxic effects induced by patulin, deoxynivalenol and toxin T2 individually and in combination in hepatic cells (HepG2). Food Chem. Toxicol. 2018, 120, 12-23. [CrossRef] [PubMed]

5. Pankaj, S.K.; Shi, H.; Keener, K.M. A review of novel physical and chemical decontamination technologies for aflatoxin in food. Trends Food Sci. Technol. 2018, 71, 73-83. [CrossRef]

6. Seyed Toutounchi, N.; Hogenkamp, A.; Varasteh, S.; van't Land, B.; Garssen, J.; Kraneveld, A.D.; Folkerts, G.; Braber, S. Fusarium Mycotoxins Disrupt the Barrier and Induce IL-6 Release in a Human Placental Epithelium Cell Line. Toxins 2019, 11, 665. [CrossRef]

7. Stanciu, O.; Loghin, F.; Filip, L.; Cozma, A.; Miere, D.; Mañes, J.; Banc, R. Occurence of Fusarium Mycotoxins in Wheat from Europe-A Review. Acta Univ. Cibiniensis. Ser. E Food Technol. 2015, 19, 35-60. [CrossRef]

8. Raghubeer, S.; Nagiah, S.; Chuturgoon, A. Ochratoxin A upregulates biomarkers associated with hypoxia and transformation in human kidney cells. Toxicol. In Vitro 2019, 57, 211-216. [CrossRef]

9. Hymery, N.; Mounier, J.; Coton, E. Effect of Penicillium roqueforti mycotoxins on Caco-2 cells: Acute and chronic exposure. Toxicol. In Vitro 2018, 48, 188-194. [CrossRef]

10. Assunção, R.; Ferreira, M.; Martins, C.; Diaz, I.; Padilla, B.; Dupont, D.; Bragança, M.; Alvito, P. Applicability of in vitro methods to study patulin bioaccessibility and its effects on intestinal membrane integrity. J. Toxicol. Environ. Heal. Part A Curr. Issues 2014, 77, 983-992. [CrossRef]

11. Hussain, S.; Asi, M.R.; Iqbal, M.; Khalid, N.; Wajih-ul-Hassan, S.; Ariño, A. Patulin Mycotoxin in Mango and Orange Fruits, Juices, Pulps, and Jams Marketed in Pakistan. Toxins 2020, 12, 52. [CrossRef] [PubMed]

12. Moss, M.O. Risk assessment for aflatoxins in foodstuffs. Int. Biodeterior. Biodegrad. 2002, 50, $137-142$. [CrossRef]

13. Rushing, B.R.; Selim, M.I. Aflatoxin B1: A review on metabolism, toxicity, occurrence in food, occupational exposure, and detoxification methods. Food Chem. Toxicol. 2019, 124, 81-100. [CrossRef] [PubMed] 
14. Rodríguez-Carrasco, Y.; Mañes, J.; Berrada, H.; Juan, C. Development and validation of a LC-ESI-MS/MS method for the determination of alternaria toxins alternariol, alternariol methyl-ether and tentoxin in tomato and tomato-based products. Toxins 2016, 8, 328. [CrossRef]

15. Gotthardt, M.; Kanawati, B.; Schmidt, F.; Asam, S.; Hammerl, R.; Frank, O.; Hofmann, T.; Schmitt-Kopplin, P.; Rychlik, M. Comprehensive Analysis of the Alternaria Mycobolome Using Mass Spectrometry Based Metabolomics. Mol. Nutr. Food Res. 2020, 64, 1900558. [CrossRef]

16. De Angelis, E.; Monaci, L.; Mackie, A.; Salt, L.; Visconti, A. Reprint of “bioaccessibility of T-2 and HT-2 toxins in mycotoxin contaminated bread models submitted to in vitro human digestion". Innov. Food Sci. Emerg. Technol. 2013, 25, 88-96. [CrossRef]

17. Ling, A.; Sun, L.; Guo, W.; Sun, S.; Yang, J.; Zhao, Z. Individual and combined cytotoxic effects of T-2 toxin and its four metabolites on porcine Leydig cells. Food Chem. Toxicol. 2020, 139, 111277. [CrossRef]

18. Huang, Z.; Wang, Y.; Qiu, M.; Sun, L.; Liao, J.; Wang, R.; Sun, X.; Bi, S.; Gooneratne, R. Effect of T-2 toxin-injected shrimp muscle extracts on mouse macrophage cells (RAW264.7). Drug Chem. Toxicol. 2018, 41, 16-21. [CrossRef]

19. Kang, R.; Perveen, A.; Li, C. Effects of maternal T-2 toxin exposure on the hepatic glycolipid metabolism in young mice. Ecotoxicol. Environ. Saf. 2020, 196, 110530. [CrossRef]

20. Kasimir, M.; Behrens, M.; Schulz, M.; Kuchenbuch, H.; Focke, C.; Humpf, H.-U. Intestinal Metabolism of $\alpha$ - and $\beta$-Glucosylated Modified Mycotoxins T-2 and HT-2 Toxin in the Pig Cecum Model. J. Agric. Food Chem. 2020. [CrossRef]

21. Schuhmacher-Wolz, U.; Heine, K.; Schneider, K. Report on toxicity data on trichothecene mycotoxins HT-2 and T-2 toxins. EFSA Support. Publ. 2010, 7. [CrossRef]

22. Zhou, H.; George, S.; Hay, C.; Lee, J.; Qian, H.; Sun, X. Individual and combined effects of Aflatoxin B1, Deoxynivalenol and Zearalenone on HepG2 and RAW 264.7 cell lines. Food Chem. Toxicol. 2017, 103, 18-27. [CrossRef] [PubMed]

23. Fernández-Blanco, C.; Font, G.; Ruiz, M.J. Interaction effects of enniatin B, deoxinivalenol and alternariol in Caco-2 cells. Toxicol. Lett. 2016, 241, 38-48. [CrossRef] [PubMed]

24. García, G.R.; Payros, D.; Pinton, P.; Dogi, C.A.; Laffitte, J.; Neves, M.; González Pereyra, M.L.; Cavaglieri, L.R.; Oswald, I.P. Intestinal toxicity of deoxynivalenol is limited by Lactobacillus rhamnosus RC007 in pig jejunum explants. Arch. Toxicol. 2018, 92, 983-993. [CrossRef]

25. Pestka, J.J. Mechanisms of deoxynivalenol-induced gene expression and apoptosis. Food Addit. Contam. Part A Chem. Anal. Control Expo. Risk Assess. 2008, 25, 1128-1140. [CrossRef]

26. Pestka, J.J.; Smolinski, A.T. Deoxynivalenol: Toxicology and potential effects on humans. J. Toxicol. Environ. Heal. Part B Crit. Rev. 2005, 8, 39-69. [CrossRef]

27. Wang, H.W.; Wang, J.Q.; Zheng, B.Q.; Li, S.L.; Zhang, Y.D.; Li, F.D.; Zheng, N. Cytotoxicity induced by ochratoxin A, zearalenone, and $\alpha$-zearalenol: Effects of individual and combined treatment. Food Chem. Toxicol. 2014, 71, 217-224. [CrossRef]

28. Yang, D.; Jiang, X.; Sun, J.; Li, X.; Li, X.; Jiao, R.; Peng, Z.; Li, Y.; Bai, W. Toxic effects of zearalenone on gametogenesis and embryonic development: A molecular point of review. Food Chem. Toxicol. 2018, 119, 24-30. [CrossRef]

29. Zinedine, A.; Soriano, J.M.; Moltó, J.C.; Mañes, J. Review on the toxicity, occurrence, metabolism, detoxification, regulations and intake of zearalenone: An oestrogenic mycotoxin. Food Chem. Toxicol. 2007, 45, 1-18. [CrossRef]

30. Ruiz, M.J.; Macáková, P.; Juan-García, A.; Font, G. Cytotoxic effects of mycotoxin combinations in mammalian kidney cells. Food Chem. Toxicol. 2011, 49, 2718-2724. [CrossRef]

31. Mallebrera, B.; Prosperini, A.; Font, G.; Ruiz, M.J. In vitro mechanisms of Beauvericin toxicity: A review. Food Chem. Toxicol. 2018, 111, 537-545. [CrossRef] [PubMed]

32. Maranghi, F.; Tassinari, R.; Narciso, L.; Tait, S.; Rocca, C.L.; Felice, G.D.; Butteroni, C.; Corinti, S.; Barletta, B.; Cordelli, E.; et al. In vivo toxicity and genotoxicity of beauvericin and enniatins. Combined approach to study in vivo toxicity and genotoxicity of mycotoxins beauvericin (BEA) and enniatin B (ENNB). EFSA Support. Publ. 2018, 15, 1406E. [CrossRef]

33. Prosperini, A.; Berrada, H.; Ruiz, M.J.; Caloni, F.; Coccini, T.; Spicer, L.J.; Perego, M.C.; Lafranconi, A. A Review of the Mycotoxin Enniatin B. Front. Public Health 2017, 5, 1-11. [CrossRef] [PubMed] 
34. Wen, J.; Mu, P.; Deng, Y. Mycotoxins: Cytotoxicity and biotransformation in animal cells. Toxicol. Res. 2016, 5, 377-387. [CrossRef]

35. Fernández-Blanco, C.; Juan-García, A.; Juan, C.; Font, G.; Ruiz, M.J. Alternariol induce toxicity via cell death and mitochondrial damage on Caco-2 cells. Food Chem. Toxicol. 2016, 88, 32-39. [CrossRef]

36. Solhaug, A.; Eriksen, G.S.; Holme, J.A. Mechanisms of Action and Toxicity of the Mycotoxin Alternariol: A Review. Basic Clin. Pharmacol. Toxicol. 2016, 119, 533-539. [CrossRef]

37. Nawaz, S.; Scudamore, K.A.; Rainbird, S.C. Mycotoxins in ingredients of animal feeding stuffs: I. determination of Alternaria mycotoxins in oilseed rape meal and sunflower seed meal. Food Addit. Contam. 1997, 14, 249-262. [CrossRef]

38. Aichinger, G.; Puntscher, H.; Beisl, J.; Kütt, M.L.; Warth, B.; Marko, D. Delphinidin protects colon carcinoma cells against the genotoxic effects of the mycotoxin altertoxin II. Toxicol. Lett. 2018, 284, 136-142. [CrossRef]

39. da Motta, S.; Valente Soares, L.M. Survey of Brazilian tomato products for alternariol, alternariol monomethyl ether, tenuazonic acid and cyclopiazonic acid. Food Addit. Contam. 2001, 18, 630-634. [CrossRef]

40. Gruber-Dorninger, C.; Novak, B.; Nagl, V.; Berthiller, F. Emerging Mycotoxins: Beyond Traditionally Determined Food Contaminants. J. Agric. Food Chem. 2017, 65, 7052-7070. [CrossRef]

41. Ge, N.; Xu, J.; Peng, B.; Pan, S. Adsorption mechanism of tenuazonic acid using inactivated lactic acid bacteria. Food Control 2017, 82, 274-282. [CrossRef]

42. Kumari, A.; Tirkey, N.N. Tenuazonic Acid: A Potent Mycotoxin. In Recent Trends in Human and Animal Mycology; Springer: Singapore, 2019; pp. 203-211.

43. Di Gregorio, M.C.; Bordin, K.; de Castro Souto, P.C.M.; Corassin, C.H.; Oliveira, C.A.F. Comparative biotransformation of aflatoxin B 1 in swine, domestic fowls, and humans. Toxin Rev. 2015, 34, 142-150. [CrossRef]

44. Wu, T.Y.; Fridley, B.L.; Jenkins, G.D.; Batzler, A.; Wang, L.; Weinshilboum, R.M. Mycophenolic acid response biomarkers: A cell line model system-based genome-wide screen. Int. Immunopharmacol. 2011, 11, 1057-1064. [CrossRef] [PubMed]

45. Marin, S.; Ramos, A.J.; Cano-Sancho, G.; Sanchis, V. Mycotoxins: Occurrence, toxicology, and exposure assessment. Food Chem. Toxicol. 2013, 60, 218-237. [CrossRef] [PubMed]

46. Fraeyman, S.; Croubels, S.; Devreese, M.; Antonissen, G. Emerging fusarium and alternaria mycotoxins: Occurrence, toxicity and toxicokinetics. Toxins 2017, 9, 228. [CrossRef]

47. González-Arias, C.A.; Crespo-Sempere, A.; Marín, S.; Sanchis, V.; Ramos, A.J. Modulation of the xenobiotic transformation system and inflammatory response by ochratoxin A exposure using a co-culture system of Caco-2 and HepG2 cells. Food Chem. Toxicol. 2015, 86, 245-252. [CrossRef]

48. Bellí, N.; Marín, S.; Sanchis, V.; Ramos, A.J. Ochratoxin A (OTA) in Wines, Musts and Grape Juices: Occurrence, Regulations and Methods of Analysis. Food Sci. Technol. Int. 2002, 8, 325-335. [CrossRef]

49. Fernández-Cruz, M.L.; Mansilla, M.L.; Tadeo, J.L. Mycotoxins in fruits and their processed products: Analysis, occurrence and health implications. J. Adv. Res. 2010, 1, 113-122. [CrossRef]

50. Orlando, B.; Grignon, G.; Vitry, C.; Kashefifard, K.; Valade, R. Fusarium species and enniatin mycotoxins in wheat, durum wheat, triticale and barley harvested in France. Mycotoxin Res. 2019, 35, 369-380. [CrossRef]

51. Tibola, C.S.; de Miranda, M.Z.; Paiva, F.F.; Fernandes, J.M.C.; Guarienti, E.M.; Nicolau, M. Effect of breadmaking process on mycotoxin content in white and whole wheat breads. Cereal Chem. 2018, 95, 660-665. [CrossRef]

52. Mousavi Khaneghah, A.; Fakhri, Y.; Sant'Ana, A.S. Impact of unit operations during processing of cereal-based products on the levels of deoxynivalenol, total aflatoxin, ochratoxin A, and zearalenone: A systematic review and meta-analysis. Food Chem. 2018, 268, 611-624. [CrossRef] [PubMed]

53. Pascari, X.; Maul, R.; Kemmlein, S.; Marin, S.; Sanchis, V. The fate of several trichothecenes and zearalenone during roasting and enzymatic treatment of cereal flour applied in cereal-based infant food production. Food Control 2020, 114, 107245. [CrossRef]

54. Generotti, S.; Cirlini, M.; Šarkanj, B.; Sulyok, M.; Berthiller, F.; Dall'Asta, C.; Suman, M. Formulation and processing factors affecting trichothecene mycotoxins within industrial biscuit-making. Food Chem. 2017, 229, 597-603. [CrossRef] [PubMed]

55. Kuchenbuch, H.S.; Becker, S.; Schulz, M.; Cramer, B.; Humpf, H.U. Thermal stability of t-2 and ht-2 toxins during biscuit-and crunchy muesli-making and roasting. Food Addit. Contam. Part A Chem. Anal. Control Expo. Risk Assess. 2018, 35, 2158-2167. [CrossRef] 
56. Serrano, A.B.; Font, G.; Mañes, J.; Ferrer, E. Effects of technological processes on enniatin levels in pasta. J. Sci. Food Agric. 2016, 96, 1756-1763. [CrossRef]

57. Tolosa, J.; Font, G.; Mañes, J.; Ferrer, E. Mitigation of enniatins in edible fish tissues by thermal processes and identification of degradation products. Food Chem. Toxicol. 2017, 101, 67-74. [CrossRef]

58. Estiarte, N.; Crespo-Sempere, A.; Marín, S.; Ramos, A.J.; Worobo, R.W. Stability of alternariol and alternariol monomethyl ether during food processing of tomato products. Food Chem. 2018, 245, 951-957. [CrossRef]

59. Stadler, D.; Berthiller, F.; Suman, M.; Schuhmacher, R.; Krska, R. Novel analytical methods to study the fate of mycotoxins during thermal food processing. Anal. Bioanal. Chem. 2020, 412, 9-16. [CrossRef]

60. Schaarschmidt, S.; Fauhl-Hassek, C. Mycotoxins during the processes of nixtamalization and tortilla production. Toxins 2019, 11, 227. [CrossRef]

61. Morcia, C.; Tumino, G.; Ghizzoni, R.; Badeck, F.W.; Lattanzio, V.M.T.; Pascale, M.; Terzi, V. Occurrence of Fusarium langsethiae and T-2 and HT-2 toxins in Italian malting barley. Toxins 2016, 8, 247. [CrossRef]

62. Agriopoulou, S.; Stamatelopoulou, E.; Varzakas, T. Control Strategies: Prevention and Detoxification in Foods. Foods 2020, 9, 137. [CrossRef] [PubMed]

63. Abrunhosa, L.; Morales, H.; Soares, C.; Calado, T.; Vila-Chã, A.S.; Pereira, M.; Venâncio, A. A Review of Mycotoxins in Food and Feed Products in Portugal and Estimation of Probable Daily Intakes. Crit. Rev. Food Sci. Nutr. 2016, 56, 249-265. [CrossRef] [PubMed]

64. Ayelign, A.; De Saeger, S. Mycotoxins in Ethiopia: Current status, implications to food safety and mitigation strategies. Food Control 2020, 113, 107163. [CrossRef]

65. Balendres, M.A.O.; Karlovsky, P.; Cumagun, C.J.R. Mycotoxigenic fungi and mycotoxins in agricultural crop commodities in the Philippines: A review. Foods 2019, 8, 249. [CrossRef] [PubMed]

66. Puntscher, H.; Cobankovic, I.; Marko, D.; Warth, B. Quantitation of free and modified Alternaria mycotoxins in European food products by LC-MS/MS. Food Control 2019, 102, 157-165. [CrossRef]

67. Meca, G.; Mañes, J.; Font, G.; Ruiz, M.J. Study of the potential toxicity of enniatins A, A 1, B, B 1 by evaluation of duodenal and colonic bioavailability applying an invitro method by Caco-2 cells. Toxicon 2012, 59, 1-11. [CrossRef]

68. Fernández-García, E.; Carvajal-Lérida, I.; Pérez-Gálvez, A. In vitro bioaccessibility assessment as a prediction tool of nutritional efficiency. Nutr. Res. 2009, 29, 751-760. [CrossRef]

69. González-Arias, C.A.; Marín, S.; Sanchis, V.; Ramos, A.J. Mycotoxin bioaccessibility/absorption assessment using in vitro digestion models: A review. World Mycotoxin J. 2013, 6, 167-184. [CrossRef]

70. Brandon, E.F.A.; Oomen, A.G.; Rompelberg, C.J.M.; Versantvoort, C.H.M.; Van Engelen, J.G.M.; Sips, A.J.A.M. Consumer product in vitro digestion model: Bioaccessibility of contaminants and its application in risk assessment. Regul. Toxicol. Pharmacol. 2006, 44, 161-171. [CrossRef]

71. Tran, V.N.; Viktorova, J.; Augustynkova, K.; Jelenova, N.; Dobiasova, S.; Rehorova, K.; Fenclova, M.; Stranska-Zachariasova, M.; Vitek, L.; Hajslova, J.; et al. In silico and in vitro studies of mycotoxins and their cocktails; Their toxicity and its mitigation by silibinin pre-treatment. Toxins 2020, 12, 148. [CrossRef]

72. Bordin, K.; Saladino, F.; Fernández-Blanco, C.; Ruiz, M.J.; Mañes, J.; Fernández-Franzón, M.; Meca, G.; Luciano, F.B. Reaction of zearalenone and $\alpha$-zearalenol with allyl isothiocyanate, characterization of reaction products, their bioaccessibility and bioavailability in vitro. Food Chem. 2017, 217, 648-654. [CrossRef]

73. Kabak, B.; Brandon, E.F.A.; Var, I.; Blokland, M.; Sips, A.J.A.M. Effects of probiotic bacteria on the bioaccessibility of aflatoxin B1 and ochratoxin A using an in vitro digestion model under fed conditions. J. Environ. Sci. Health Part B Pestic. Food Contam. Agric. Wastes 2009, 44, 472-480. [CrossRef]

74. CenciČ, A.; Langerholc, T. Functional cell models of the gut and their applications in food microbiologyA review. Int. J. Food Microbiol. 2010, 141, S4-S14. [CrossRef]

75. Artursson, P.; Karlsson, J. Correlation between oral drug absorption in humans and apparent drug permeability coefficients in human intestinal epithelial (Caco-2) cells. Biochem. Biophys. Res. Commun. 1991, 175, 880-885. [CrossRef]

76. Brandon, E.F.A.; Bosch, T.M.; Deenen, M.J.; Levink, R.; van der Wal, E.; van Meerveld, J.B.M.; Bijl, M.; Beijnen, J.H.; Schellens, J.H.M.; Meijerman, I. Validation of in vitro cell models used in drug metabolism and transport studies; genotyping of cytochrome P450, phase II enzymes and drug transporter polymorphisms in the human hepatoma (HepG2), ovarian carcinoma (IGROV-1) and colon carcinoma (CaCo-2, LS180) cell lines. Toxicol. Appl. Pharmacol. 2006, 211,1-10. 
77. Lněničková, K.; Šadibolová, M.; Matoušková, P.; Szotáková, B.; Skálová, L.; Boušová, I. The Modulation of Phase II Drug-Metabolizing Enzymes in Proliferating and Differentiated CaCo-2 Cells by Hop-Derived Prenylflavonoids. Nutrients 2020, 12, 2138. [CrossRef]

78. Schaut, A.; De Saeger, S.; Sergent, T.; Schneider, Y.-J.; Larondelle, Y.; Pussemier, L.; Van Peteghem, C. Study of the gastrointestinal biotransformation of zearalenone in a Caco-2 cell culture system with liquid chromatographic methods. J. Appl. Toxicol. 2008, 28, 966-973. [CrossRef]

79. Cizkova, K. Expression of cytochrome P450 epoxygenases and soluble epoxide hydrolase is regulated by hypolipidemic drugs in dose-dependent manner. Toxicol. Appl. Pharmacol. 2018, 355, 156-163. [CrossRef]

80. Šemeláková, M.; Jendželovský, R.; Fedoročko, P. Drug membrane transporters and CYP3A4 are affected by hypericin, hyperforin or aristoforin in colon adenocarcinoma cells. Biomed. Pharmacother. 2016, 81, 38-47. [CrossRef]

81. Odenthal, J.; van Heumen, B.W.H.; Roelofs, H.M.J.; te Morsche, R.H.M.; Marian, B.; Nagengast, F.M.; Peters, W.H.M. The Influence of Curcumin, Quercetin, and Eicosapentaenoic Acid on the Expression of Phase II Detoxification Enzymes in the Intestinal Cell Lines HT-29, Caco-2, HuTu 80, and LT97. Nutr. Cancer 2012, 64, 856-863. [CrossRef]

82. Langerholc, T.; Maragkoudakis, P.A.; Wollgast, J.; Gradisnik, L.; Cencic, A. Novel and established intestinal cell line models-An indispensable tool in food science and nutrition. Trends Food Sci. Technol. 2011, 22, S11-S20. [CrossRef]

83. Haslam, I.S.; Jones, K.; Coleman, T.; Simmons, N.L. Induction of P-glycoprotein expression and function in human intestinal epithelial cells (T84). Biochem. Pharmacol. 2008, 76, 850-861. [CrossRef]

84. Naruhashi, K.; Kurahashi, Y.; Fujita, Y.; Kawakita, E.; Yamasaki, Y.; Hattori, K.; Nishimura, A.; Shibata, N. Comparison of the Expression and Function of ATP Binding Cassette Transporters in Caco-2 and T84 cells on Stimulation by Selected Endogenous Compounds and Xenobiotics. Drug Metab. Pharmacokinet. 2011, 26, 145-153. [CrossRef]

85. Theodoropoulos, C.; Demers, C.; Delvin, E.; Menard, D.; Gascon-Barre, M. Calcitriol regulates the expression of the genes encoding the three key vitamin D3 hydroxylases and the drug-metabolizing enzyme CYP3A4 in the human fetal intestine. Clin. Endocrinol. 2003, 58, 489-499. [CrossRef]

86. Saaby, L.; Helms, H.C.C.; Brodin, B. IPEC-J2 MDR1, a Novel High-Resistance Cell Line with Functional Expression of Human P-glycoprotein (ABCB1) for Drug Screening Studies. Mol. Pharm. 2016, 13, 640-652. [CrossRef]

87. Palócz, O.; Szita, G.; Csikó, G. Alteration in Inflammatory Responses and Cytochrome P450 Expression of Porcine Jejunal Cells by Drinking Water Supplements. Mediators Inflamm. 2019, 2019. [CrossRef]

88. Loi, M.; Fanelli, F.; Liuzzi, V.C.; Logrieco, A.F.; Mulè, G. Mycotoxin biotransformation by native and commercial enzymes: Present and future perspectives. Toxins 2017, 9, 111. [CrossRef]

89. Beyerle, J.; Frei, E.; Stiborova, M.; Habermann, N.; Ulrich, C.M. Biotransformation of xenobiotics in the human colon and rectum and its association with colorectal cancer. Drug Metab. Rev. 2015, 47, 199-221. [CrossRef]

90. Gajecka, M.; Jakimiuk, E.; Zielonka, L.; Obremski, K.; Gajecka, M. The Biotransformation of Chosen Mycotoxins. Pol. J. Vet Sci. 2009, 12, 293-303.

91. Galtier, P. Biotransformation and Fate of Mycotoxins. J. Toxicol. Toxin Rev. 1999, 18, $295-312$.

92. Sergent, T.; Ribonnet, L.; Kolosova, A.; Garsou, S.; Schaut, A.; De Saeger, S.; Van Peteghem, C.; Larondelle, Y.; Pussemier, L.; Schneider, Y.J. Molecular and cellular effects of food contaminants and secondary plant components and their plausible interactions at the intestinal level. Food Chem. Toxicol. 2008, 46, 813-841. [CrossRef]

93. Lin, N.N.; Chen, J.; Xu, B.; Wei, X.; Guo, L.; Xie, J.W. The roles of carboxylesterase and CYP isozymes on the in vitro metabolism of T-2 toxin. Mil. Med. Res. 2015, 2, 13. [CrossRef]

94. Wang, J.; Jiang, J.; Zhang, H.; Wang, J.; Cai, H.; Li, C.; Li, K.; Liu, J.; Guo, X.; Zou, G.; et al. Integrated transcriptional and proteomic analysis with in vitro biochemical assay reveal the important role of CYP3A46 in T-2 toxin hydroxylation in porcine primary hepatocytes. Mol. Cell. Proteom. 2011, 10. [CrossRef]

95. Wu, Q.; Huang, L.; Liu, Z.; Yao, M.; Wang, Y.; Dai, M.; Yuan, Z. A comparison of hepatic in vitro metabolism of T-2 toxin in rats, pigs, chickens, and carp. Xenobiotica 2011, 41, 863-873. [CrossRef] 
96. Ge, X.; Wang, J.; Liu, J.; Jiang, J.; Lin, H.; Wu, J.; Ouyang, M.; Tang, X.; Zheng, M.; Liao, M.; et al. The catalytic activity of cytochrome P450 3A22 is critical for the metabolism of T-2 toxin in porcine reservoirs. Catal. Commun. 2010, 12, 71-75. [CrossRef]

97. Yuan, Y.; Zhou, X.; Yang, J.; Li, M.; Qiu, X. T-2 toxin is hydroxylated by chicken CYP3A37. Food Chem. Toxicol. 2013, 62, 622-627. [CrossRef]

98. Shang, S.; Jiang, J.; Deng, Y. Chicken cytochrome P450 1A5 is the key enzyme for metabolizing T-2 toxin to 3'OH-T-2. Int. J. Mol. Sci. 2013, 14, 10809-10818. [CrossRef]

99. Dai, D.; Pan, Y.; Zeng, C.P.; Liu, S.; Yan, Y.; Wu, X.; Xu, Z.; Zhang, L. Activated FXR promotes xenobiotic metabolism of T-2 toxin and attenuates oxidative stress in broiler chicken liver. Chem. Biol. Interact. 2020, 316, 108912. [CrossRef]

100. Deng, Y.; Wang, Y.; Sun, L.; Lu, P.; Wang, R.; Ye, L.; Xu, D.; Ye, R.; Liu, Y.; Bi, S.; et al. Biotransformation enzyme activities and phase I metabolites analysis in Litopenaeus vannamei following intramuscular administration of T-2 toxin. Drug Chem. Toxicol. 2018, 41, 113-122. [CrossRef]

101. Wang, Y.; Wang, G.; Dai, Y.; Wang, Y.; Lee, Y.W.; Shi, J.; Xu, J. Biodegradation of Deoxynivalenol by a Novel Microbial Consortium. Front. Microbiol. 2020, 10, 2964. [CrossRef]

102. Wu, Q.H.; Wang, X.; Yang, W.; Nüssler, A.K.; Xiong, L.Y.; Kuča, K.; Dohnal, V.; Zhang, X.J.; Yuan, Z.H. Oxidative stress-mediated cytotoxicity and metabolism of T-2 toxin and deoxynivalenol in animals and humans: An update. Arch. Toxicol. 2014, 88, 1309-1326. [CrossRef] [PubMed]

103. Catteuw, A.; Broekaert, N.; De Baere, S.; Lauwers, M.; Gasthuys, E.; Huybrechts, B.; Callebaut, A.; Ivanova, L.; Uhlig, S.; De Boevre, M.; et al. Insights into in Vivo Absolute Oral Bioavailability, Biotransformation, and Toxicokinetics of Zearalenone, $\alpha$-Zearalenol, $\beta$-Zearalenol, Zearalenone-14-glucoside, and Zearalenone-14-sulfate in Pigs. J. Agric. Food Chem. 2019, 67, 3448-3458. [CrossRef] [PubMed]

104. Malekinejad, H.; Maas-Bakker, R.; Fink-Gremmels, J. Species differences in the hepatic biotransformation of zearalenone. Vet. J. 2006, 172, 96-102. [CrossRef] [PubMed]

105. Malekinejad, H.; Maas-Bakker, R.F.; Fink-Gremmels, J. Bioactivation of zearalenone by porcine hepatic biotransformation. Vet. Res. 2005, 36, 799-810. [CrossRef]

106. Ayed-Boussema, I.; Pascussi, J.M.; Maurel, P.; Bacha, H.; Hassen, W. Zearalenone activates pregnane $X$ receptor, constitutive androstane receptor and aryl hydrocarbon receptor and corresponding phase I target genes mRNA in primary cultures of human hepatocytes. Environ. Toxicol. Pharmacol. 2011, 31, 79-87. [CrossRef]

107. Rodríguez-Carrasco, Y.; Heilos, D.; Richter, L.; Süssmuth, R.D.; Heffeter, P.; Sulyok, M.; Kenner, L.; Berger, W.; Dornetshuber-Fleiss, R. Mouse tissue distribution and persistence of the food-born fusariotoxins Enniatin B and Beauvericin. Toxicol. Lett. 2016, 247,35-44. [CrossRef]

108. Mei, L.; Zhang, L.; Dai, R. An inhibition study of beauvericin on human and rat cytochrome P450 enzymes and its pharmacokinetics in rats. J. Enzym. Inhib. Med. Chem. 2009, 24, 753-762. [CrossRef]

109. Fæste, C.K.; Ivanova, L.; Uhlig, S. In vitro metabolism of the mycotoxin enniatin B in different species and cytochrome P450 enzyme phenotyping by chemical inhibitors. Drug Metab. Dispos. 2011, 39, 1768-1776. [CrossRef]

110. Ivanova, L.; Fæste, C.K.; Uhlig, S. In vitro phase i metabolism of the depsipeptide enniatin B. Anal. Bioanal. Chem. 2011, 400, 2889-2901. [CrossRef]

111. Ivanova, L.; Fæste, C.K.; Van Pamel, E.; Daeseleire, E.; Callebaut, A.; Uhlig, S. Presence of enniatin B and its hepatic metabolites in plasma and liver samples from broilers and eggs from laying hens. World Mycotoxin J. 2014, 7, 167-175. [CrossRef]

112. Ivanova, L.; Denisov, I.G.; Grinkova, Y.V.; Sligar, S.G.; Fæste, C.K. Biotransformation of the Mycotoxin Enniatin B1 by CYP P450 3A4 and Potential for Drug-Drug Interactions. Metabolites 2019, 9, 158. [CrossRef] [PubMed]

113. Ivanova, L.; Uhlig, S.; Devreese, M.; Croubels, S.; Fæste, C.K. Biotransformation of the mycotoxin enniatin B1 in pigs: A comparative in vitro and in vivo approach. Food Chem. Toxicol. 2017, 105, 506-517. [CrossRef] [PubMed]

114. Debevere, S.; Cools, A.; De Baere, S.; Haesaert, G.; Rychlik, M.; Croubels, S.; Fievez, V. In Vitro Rumen Simulations Show a Reduced Disappearance of Deoxynivalenol, Nivalenol and Enniatin B at Conditions of Rumen Acidosis and Lower Microbial Activity. Toxins 2020, 12, 101. [CrossRef] [PubMed] 
115. Fraeyman, S.; Devreese, M.; Antonissen, G.; De Baere, S.; Rychlik, M.; Croubels, S. Comparative Oral Bioavailability, Toxicokinetics, and Biotransformation of Enniatin B1 and Enniatin B in Broiler Chickens. J. Agric. Food Chem. 2016, 64, 7259-7264. [CrossRef] [PubMed]

116. Müller, S.; Dekant, W.; Mally, A. Fumonisin B 1 and the kidney: Modes of action for renal tumor formation by fumonisin B 1 in rodents. Food Chem. Toxicol. 2012, 50, 3833-3846. [CrossRef]

117. Schreck, I.; Deigendesch, U.; Burkhardt, B.; Marko, D.; Weiss, C. The Alternaria mycotoxins alternariol and alternariol methyl ether induce cytochrome P450 1A1 and apoptosis in murine hepatoma cells dependent on the aryl hydrocarbon receptor. Arch. Toxicol. 2012, 86, 625-632. [CrossRef]

118. Aichinger, G.; Krüger, F.; Puntscher, H.; Preindl, K.; Warth, B.; Marko, D. Naturally occurring mixtures of Alternaria toxins: Anti-estrogenic and genotoxic effects in vitro. Arch. Toxicol. 2019, 93, 3021-3031. [CrossRef]

119. Burkhardt, B.; Pfeiffer, E.; Metzler, M. Absorption and metabolism of the mycotoxins alternariol and alternariol-9-methyl ether in Caco-2 cells in vitro. Mycotoxin Res. 2009, 25, 149-157. [CrossRef]

120. Scheibenzuber, S.; Hoffmann, T.; Effenberger, I.; Schwab, W.; Asam, S.; Rychlik, M. Enzymatic synthesis of modified alternaria mycotoxins using a whole-cell biotransformation system. Toxins 2020, 12, 264. [CrossRef]

121. Puntscher, H.; Hankele, S.; Tillmann, K.; Attakpah, E.; Braun, D.; Kütt, M.L.; Del Favero, G.; Aichinger, G.; Pahlke, G.; Höger, H.; et al. First insights into Alternaria multi-toxin in vivo metabolism. Toxicol. Lett. 2019, 301, 168-178. [CrossRef]

122. Yang, X.J.; Lu, H.Y.; Li, Z.Y.; Bian, Q.; Qiu, L.L.; Li, Z.; Liu, Q.; Li, J.; Wang, X.; Wang, S.L. Cytochrome P450 2A13 mediates aflatoxin B1-induced cytotoxicity and apoptosis in human bronchial epithelial cells. Toxicology 2012, 300, 138-148. [CrossRef] [PubMed]

123. Deng, J.; Zhao, L.; Zhang, N.Y.; Karrow, N.A.; Krumm, C.S.; Qi, D.S.; Sun, L.H. Aflatoxin B 1 metabolism: Regulation by phase I and II metabolizing enzymes and chemoprotective agents. Mutat. Res. Rev. Mutat. Res. 2018, 778, 79-89. [CrossRef] [PubMed]

124. Ayed-Boussema, I.; Pascussi, J.M.; Zaied, C.; Maurel, P.; Bacha, H.; Hassen, W. Ochratoxin A induces CYP3A4, 2B6, 3A5, 2C9, 1A1, and CYP1A2 gene expression in primary cultured human hepatocytes: A possible activation of nuclear receptors. Drug Chem. Toxicol. 2012, 35, 71-80. [CrossRef] [PubMed]

125. Shin, H.S.; Lee, H.J.; Pyo, M.C.; Ryu, D.; Lee, K.W. Ochratoxin a-induced hepatotoxicity through phase i and phase ii reactions regulated by ahr in liver cells. Toxins 2019, 11, 377. [CrossRef]

126. Tao, Y.; Xie, S.; Xu, F.; Liu, A.; Wang, Y.; Chen, D.; Pan, Y.; Huang, L.; Peng, D.; Wang, X.; et al. Ochratoxin A: Toxicity, oxidative stress and metabolism. Food Chem. Toxicol. 2018, 112, 320-331. [CrossRef]

127. Gross-Steinmeyer, K.; Weymann, J.; Hege, H.G.; Metzler, M. Metabolism and lack of DNA reactivity of the mycotoxin ochratoxin A in cultured rat and human primary hepatocytes. J. Agric. Food Chem. 2002, 50, 938-945. [CrossRef]

128. Tozlovanu, M.; Canadas, D.; Pfohl-Leszkowicz, A.; Frenette, C.; Paugh, R.J.; Manderville, R.A. Glutathione conjugates of ochratoxin a as biomarkers of exposure. Arh. Hig. Rada Toksikol. 2012, 63, 417-425. [CrossRef]

129. Kőszegi, T.; Poór, M. Ochratoxin a: Molecular interactions, mechanisms of toxicity and prevention at the molecular level. Toxins 2016, 8, 111. [CrossRef]

130. Ayed-Boussema, I.; Pascussi, J.M.; Rjiba, K.; Maurel, P.; Bacha, H.; Hassen, W. The mycotoxin, patulin, increases the expression of PXR and AhR and their target cytochrome P450s in primary cultured human hepatocytes. Drug Chem. Toxicol. 2012, 35, 241-250. [CrossRef]

131. Ji, C.; Fan, Y.; Zhao, L. Review on biological degradation of mycotoxins. Anim. Nutr. 2016, 2, 127-133. [CrossRef]

132. Young, J.C.; Zhou, T.; Yu, H.; Zhu, H.; Gong, J. Degradation of trichothecene mycotoxins by chicken intestinal microbes. Food Chem. Toxicol. 2007, 45, 136-143. [CrossRef] [PubMed]

133. Pierron, A.; Mimoun, S.; Murate, L.S.; Loiseau, N.; Lippi, Y.; Bracarense, A.P.F.L.; Schatzmayr, G.; He, J.W.; Zhou, T.; Moll, W.D.; et al. Microbial biotransformation of DON: Molecular basis for reduced toxicity. Sci. Rep. 2016, 6, 29105. [CrossRef] [PubMed]

134. Du, K.; Wang, C.; Liu, P.; Li, Y.; Ma, X. Effects of Dietary Mycotoxins on Gut Microbiome. Protein Pept. Lett. 2017, 24, 397-405. [CrossRef] [PubMed] 
135. Antonissen, G.; Devreese, M.; De Baere, S.; Martel, A.; Van Immerseel, F.; Croubels, S. Impact of Fusarium mycotoxins on hepatic and intestinal mRNA expression of cytochrome P450 enzymes and drug transporters, and on the pharmacokinetics of oral enrofloxacin in broiler chickens. Food Chem. Toxicol. 2017, 101, 75-83. [CrossRef] [PubMed]

136. Murcia, H.W.; Diaz, G.J. In vitro hepatic aflatoxicol production is related to a higher resistance to aflatoxin B1 in poultry. Sci. Rep. 2020, 10, 5508. [CrossRef]

137. Gross-Steinmeyer, K.; Eaton, D.L. Dietary modulation of the biotransformation and genotoxicity of aflatoxin B1. Toxicology 2012, 299, 69-79. [CrossRef]

138. Peles, F.; Sipos, P.; Győri, Z.; Pfliegler, W.P.; Giacometti, F.; Serraino, A.; Pagliuca, G.; Gazzotti, T.; Pócsi, I. Adverse Effects, Transformation and Channeling of Aflatoxins Into Food Raw Materials in Livestock. Front. Microbiol. 2019, 10, 1-26. [CrossRef]

139. Wu, J.; Xu, W.; Zhang, C.; Chang, Q.; Tang, X.; Li, K.; Deng, Y. Trp266 determines the binding specificity of a porcine aflatoxin B 1 aldehyde reductase for aflatoxin B1-dialdehyde. Biochem. Pharmacol. 2013, 86, 1357-1365. [CrossRef]

140. Lyagin, I.; Efremenko, E. Enzymes for Detoxification of Various Mycotoxins: Origins and Mechanisms of Catalytic Action. Molecules 2019, 24, 2362. [CrossRef]

141. Schrenk, D.; Bodin, L.; Chipman, J.K.; del Mazo, J.; Grasl-Kraupp, B.; Hogstrand, C.; Hoogenboom, L. (Ron); Leblanc, J.; Nebbia, C.S.; Nielsen, E.; et al. Risk assessment of ochratoxin A in food. EFSA J. 2020, 18. [CrossRef]

142. Li, P.; Su, R.; Yin, R.; Lai, D.; Wang, M.; Liu, Y.; Zhou, L. Detoxification of mycotoxins through biotransformation. Toxins 2020, 12, 121. [CrossRef] [PubMed]

143. Ringot, D.; Chango, A.; Schneider, Y.-J.; Larondelle, Y. Toxicokinetics and toxicodynamics of ochratoxin A, an update. Chem. Biol. Interact. 2006, 159, 18-46. [CrossRef] [PubMed]

144. Wu, Q.; Dohnal, V.; Huang, L.; Kuca, K.; Wang, X.; Chen, G.; Yuan, Z. Metabolic Pathways of Ochratoxin A. Curr. Drug Metab. 2011, 12, 1-10. [CrossRef] [PubMed]

145. Schelstraete, W.; Devreese, M.; Croubels, S. Impact of subacute exposure to T-2 toxin and zearalenone on the pharmacokinetics of midazolam as CYP3A probe drug in a porcine animal model: A pilot study. Front. Pharmacol. 2019, 10, 399. [CrossRef] [PubMed]

146. Payros, D.; Alassane-Kpembi, I.; Pierron, A.; Loiseau, N.; Pinton, P.; Oswald, I.P. Toxicology of deoxynivalenol and its acetylated and modified forms. Arch. Toxicol. 2016, 90, 2931-2957. [CrossRef] [PubMed]

147. Springler, A.; Hessenberger, S.; Reisinger, N.; Kern, C.; Nagl, V.; Schatzmayr, G.; Mayer, E. Deoxynivalenol and its metabolite deepoxy-deoxynivalenol: Multi-parameter analysis for the evaluation of cytotoxicity and cellular effects. Mycotoxin Res. 2017, 33, 25-37. [CrossRef]

148. Nagl, V.; Woechtl, B.; Schwartz-Zimmermann, H.E.; Hennig-Pauka, I.; Moll, W.D.; Adam, G.; Berthiller, F. Metabolism of the masked mycotoxin deoxynivalenol-3-glucoside in pigs. Toxicol. Lett. 2014, 229, 190-197. [CrossRef]

149. Schwartz, H.E.; Hametner, C.; Slavik, V.; Greitbauer, O.; Bichl, G.; Kunz-Vekiru, E.; Schatzmayr, D.; Berthiller, F. Characterization of three deoxynivalenol sulfonates formed by reaction of deoxynivalenol with sulfur reagents. J. Agric. Food Chem. 2013, 61, 8941-8948. [CrossRef]

150. Gerding, J.; Cramer, B.; Humpf, H.U. Determination of mycotoxin exposure in Germany using an LC-MS/MS multibiomarker approach. Mol. Nutr. Food Res. 2014, 58, 2358-2368. [CrossRef]

151. Pestka, J.J. Deoxynivalenol: Toxicity, mechanisms and animal health risks. Anim. Feed Sci. Technol. 2007, 137, 283-298. [CrossRef]

152. Gao, X.; Mu, P.; Zhu, X.; Chen, X.; Tang, S.; Wu, Y.; Miao, X.; Wang, X.; Wen, J.; Deng, Y. Dual function of a novel bacterium, slackia sp. D-G6: Detoxifying deoxynivalenol and producing the Natural Estrogen Analogue, Equol. Toxins 2020, 12, 85. [CrossRef] [PubMed]

153. Mackei, M.; Orbán, K.; Molnár, A.; Pál, L.; Dublecz, K.; Husvéth, F.; Neogrády, Z.; Mátis, G. Cellular Effects of T-2 Toxin on Primary Hepatic Cell Culture Models of Chickens. Toxins 2020, 12, 46. [CrossRef] [PubMed]

154. Li, Y.; Wang, Z.; Beier, R.C.; Shen, J.; De Smet, D.; De Saeger, S.; Zhang, S. T-2 toxin, a trichothecene mycotoxin: Review of toxicity, metabolism, and analytical methods. J. Agric. Food Chem. 2011, 59, 3441-3453. [CrossRef] [PubMed] 
155. Welsch, T.; Humpf, H.U. HT-2 toxin 4-glucuronide as new T-2 toxin metabolite: Enzymatic synthesis, analysis, and species specific formation of T-2 and HT-2 toxin glucuronides by rat, mouse, pig, and human liver microsomes. J. Agric. Food Chem. 2012, 60, 10170-10178. [CrossRef]

156. Masching, S.; Naehrer, K.; Schwartz-Zimmermann, H.E.; Sărăndan, M.; Schaumberger, S.; Dohnal, I.; Nagl, V.; Schatzmayr, D. Gastrointestinal degradation of fumonisin B1 by carboxylesterase FumD prevents fumonisin induced alteration of sphingolipid metabolism in Turkey and swine. Toxins 2016, 8, 84. [CrossRef]

157. Daud, N.; Currie, V.; Duncan, G.; Busman, M.; Gratz, S.W. Intestinal hydrolysis and microbial biotransformation of diacetoxyscirpenol- $\alpha$-glucoside, HT-2- $\beta$-glucoside and N-(1-deoxy-d-fructos-1-yl) fumonisin B1 by human gut microbiota in vitro. Int. J. Food Sci. Nutr. 2019, 71, 540-548. [CrossRef]

158. Merrill, A.H.; Morgan, E.T.; Nikolova-Karakashian, M.; Stewart, J. Sphingomyelin hydrolysis and regulation of the expression of the gene for cytochrome P450. Biochem. Soc. Trans. 1999, 27, 383-387. [CrossRef]

159. Spotti, M.; Maas, R.F.M.; De Nijs, C.M.; Fink-Gremmels, J. Effect of fumonisin B1 on rat hepatic P450 system. Environ. Toxicol. Pharmacol. 2000, 8, 197-204. [CrossRef]

160. Riley, R.T.; Merrill, A.H. Ceramide synthase inhibition by fumonisins: A perfect storm of perturbed sphingolipid metabolism, signaling, and disease. J. Lipid Res. 2019, 60, 1183-1189. [CrossRef]

161. Harrer, H.; Laviad, E.L.; Humpf, H.U.; Futerman, A.H. Identification of N-acyl-fumonisin B1 as new cytotoxic metabolites of fumonisin mycotoxins. Mol. Nutr. Food Res. 2013, 57, 516-522. [CrossRef]

162. Dellafiora, L.; Galaverna, G.; Dall'Asta, C. Mechanisms of Fumonisin B1 Toxicity: A Computational Perspective beyond the Ceramide Synthases Inhibition. Chem. Res. Toxicol. 2018, 31, 1203-1212. [CrossRef] [PubMed]

163. Knutsen, H.K.; Alexander, J.; Barregård, L.; Bignami, M.; Brüschweiler, B.; Ceccatelli, S.; Cottrill, B.; Dinovi, M.; Edler, L.; Grasl-Kraupp, B.; et al. Risks for animal health related to the presence of fumonisins, their modified forms and hidden forms in feed. EFSA J. 2018, 16, e05242. [PubMed]

164. Ieko, T.; Inoue, S.; Inomata, Y.; Inoue, H.; Fujiki, J.; Iwano, H. Glucuronidation as a metabolic barrier against zearalenone in rat everted intestine. J. Vet. Med. Sci. 2020, 82, 153-161. [CrossRef] [PubMed]

165. Binder, S.B.; Schwartz-Zimmermann, H.E.; Varga, E.; Bichl, G.; Michlmayr, H.; Adam, G.; Berthiller, F. Metabolism of zearalenone and its major modified forms in pigs. Toxins 2017, 9, 56. [CrossRef]

166. Videmann, B.; Mazallon, M.; Tep, J.; Lecoeur, S. Metabolism and transfer of the mycotoxin zearalenone in human intestinal Caco-2 cells. Food Chem. Toxicol. 2008, 46, 3279-3286. [CrossRef]

167. Dellafiora, L.; Galaverna, G.; Righi, F.; Cozzini, P.; Dall'Asta, C. Assessing the hydrolytic fate of the masked mycotoxin zearalenone-14-glucoside-A warning light for the need to look at the "maskedome". Food Chem. Toxicol. 2017, 99, 9-16. [CrossRef]

168. Keller, L.; Abrunhosa, L.; Keller, K.; Rosa, C.; Cavaglieri, L.; Venâncio, A. Zearalenone and Its Derivatives $\alpha$-Zearalenol and $\beta$-Zearalenol Decontamination by Saccharomyces cerevisiae Strains Isolated from Bovine Forage. Toxins 2015, 7, 3297-3308. [CrossRef]

169. Rogowska, A.; Pomastowski, P.; Walczak, J.; Railean-Plugaru, V.; Rudnicka, J.; Buszewski, B. Investigation of zearalenone adsorption and biotransformation by microorganisms cultured under cellular stress conditions. Toxins 2019, 11, 463. [CrossRef]

170. Rogowska, A.; Pomastowski, P.; Rafińska, K.; Railean-Plugaru, V.; Złoch, M.; Walczak, J.; Buszewski, B. A study of zearalenone biosorption and metabolisation by prokaryotic and eukaryotic cells. Toxicon 2019, 169, 81-90. [CrossRef]

171. Chlebicz, A.; Śliżewska, K. In Vitro Detoxification of Aflatoxin B1, Deoxynivalenol, Fumonisins, T-2 Toxin and Zearalenone by Probiotic Bacteria from Genus Lactobacillus and Saccharomyces cerevisiae Yeast. Probiotics Antimicrob. Proteins 2020, 12, 289-301. [CrossRef]

172. Pfeiffer, E.; Schebb, N.H.; Podlech, J.; Metzler, M. Novel oxidative in vitro metabolites of the mycotoxins alternariol and alternariol methyl ether. Mol. Nutr. Food Res. 2007, 51, 307-316. [CrossRef] [PubMed]

173. Pfeiffer, E.; Burkhardt, B.; Altemöller, M.; Podlech, J.; Metzler, M. Activities of human recombinant cytochrome P450 isoforms and human hepatic microsomes for the hydroxylation ofAlternaria toxins. Mycotoxin Res. 2008, 24, 117-123. [CrossRef] [PubMed]

174. Tiessen, C.; Ellmer, D.; Mikula, H.; Pahlke, G.; Warth, B.; Gehrke, H.; Zimmermann, K.; Heiss, E.; Fröhlich, J.; Marko, D. Impact of phase I metabolism on uptake, oxidative stress and genotoxicity of the emerging mycotoxin alternariol and its monomethyl ether in esophageal cells. Arch. Toxicol. 2017, 91, 1213-1226. [CrossRef] [PubMed] 
175. Lemke, A.; Burkhardt, B.; Bunzel, D.; Pfeiffer, E.; Metzler, M.; Huch, M.; Kulling, S.E.; Franz, C.M.A.P. Alternaria toxins of the alternariol type are not metabolised by human faecal microbiota. World Mycotoxin J. 2016, 9, 41-49. [CrossRef]

176. Fleck, S.C.; Pfeiffer, E.; Podlech, J.; Metzler, M. Epoxide Reduction to an Alcohol: A Novel Metabolic Pathway for Perylene Quinone-Type Alternaria Mycotoxins in Mammalian Cells. Chem. Res. Toxicol. 2014, 27, $247-253$. [CrossRef]

177. Burkhardt, B.; Wittenauer, J.; Pfeiffer, E.; Schauer, U.M.D.; Metzler, M. Oxidative metabolism of the mycotoxins alternariol and alternariol-9-methyl ether in precision-cut rat liver slices in vitro. Mol. Nutr. Food Res. 2011, 55, 1079-1086. [CrossRef]

178. Pfeiffer, E.; Schmit, C.; Burkhardt, B.; Altemöller, M.; Podlech, J.; Metzler, M. Glucuronidation of the mycotoxins alternariol and alternariol-9-methyl ether in vitro: Chemical structures of glucuronides and activities of human UDP-glucuronosyltransferase isoforms. Mycotoxin Res. 2009, 25, 3-10. [CrossRef]

179. Soukup, S.T.; Kohn, B.N.; Pfeiffer, E.; Geisen, R.; Metzler, M.; Bunzel, M.; Kulling, S.E. Sulfoglucosides as Novel Modified Forms of the Mycotoxins Alternariol and Alternariol Monomethyl Ether. J. Agric. Food Chem. 2016, 64, 8892-8901. [CrossRef]

180. Puntscher, H.; Marko, D.; Warth, B. The fate of altertoxin ii during tomato processing steps at a laboratory scale. Front. Nutr. 2019, 6, 92. [CrossRef]

181. Pfeiffer, E.; Herrmann, C.; Altemöller, M.; Podlech, J.; Metzler, M. Oxidative in vitro metabolism of the Alternaria toxins altenuene and isoaltenuene. Mol. Nutr. Food Res. 2009, 53, 452-459. [CrossRef]

182. Rychlik, M.; Kircher, F.; Schusdziarra, V.; Lippl, F. Absorption of the mycotoxin patulin from the rat stomach. Food Chem. Toxicol. 2004, 42, 729-735. [CrossRef] [PubMed]

183. Rychlik, M. Rapid degradation of the mycotoxin patulin in man quantified by stable isotope dilution assays. Food Addit. Contam. 2003, 20, 829-837. [CrossRef] [PubMed]

184. Zheng, X.; Wei, W.; Rao, S.; Gao, L.; Li, H.; Yang, Z. Degradation of patulin in fruit juice by a lactic acid bacteria strain Lactobacillus casei YZU01. Food Control 2020, 112, 107147. [CrossRef]

185. Tannous, J.; Snini, S.P.; El Khoury, R.; Canlet, C.; Pinton, P.; Lippi, Y.; Alassane-Kpembi, I.; Gauthier, T.; El Khoury, A.; Atoui, A.; et al. Patulin transformation products and last intermediates in its biosynthetic pathway, E- and Z-ascladiol, are not toxic to human cells. Arch. Toxicol. 2017, 91, 2455-2467. [CrossRef]

186. Ianiri, G.; Idnurm, A.; Wright, S.A.I.; Durán-Patrón, R.; Mannina, L.; Ferracane, R.; Ritieni, A.; Castoria, R. Searching for genes responsible for patulin degradation in a biocontrol yeast provides insight into the basis for resistance to this mycotoxin. Appl. Environ. Microbiol. 2013, 79, 3101-3115. [CrossRef]

187. Xu, R.; Zhu, H.; Hu, L.; Yu, B.; Zhan, X.; Yuan, Y.; Zhou, P. Characterization of the intestinal absorption of morroniside from Cornus officinalis Sieb. et Zucc via a Caco-2 cell monolayer model. PLoS ONE 2020, 15, e0227844. [CrossRef]

188. Zhang, J.; Zheng, N.; Liu, J.; Li, F.D.; Li, S.L.; Wang, J.Q. Aflatoxin B1 and aflatoxin M1 induced cytotoxicity and DNA damage in differentiated and undifferentiated Caco-2 cells. Food Chem. Toxicol. 2015, 83, 54-60. [CrossRef]

189. Fogh, J.; Fogh, J.M.; Orfeo, T. One Hundred and Twenty-Seven Cultured Human Tumor Cell Lines Producing Tumors in Nude Mice23. JNCI J. Natl. Cancer Inst. 1977, 59, 221-226. [CrossRef]

190. Iftikhar, M.; Iftikhar, A.; Zhang, H.; Gong, L.; Wang, J. Transport, metabolism and remedial potential of functional food extracts (FFEs) in Caco-2 cells monolayer: A Review. Food Res. Int. 2020, 136, 109240. [CrossRef]

191. Kamiloglu, S.; Capanoglu, E.; Grootaert, C.; Van Camp, J. Anthocyanin Absorption and Metabolism by Human Intestinal Caco-2 Cells-A Review. Int. J. Mol. Sci. 2015, 16, 21555-21574. [CrossRef]

192. Awortwe, C.; Fasinu, P.S.; Rosenkranz, B. Application of Caco-2 cell line in herb-drug interaction studies: Current approaches and challenges. J. Pharm. Pharm. Sci. Publ. Can. Soc. Pharm. Sci. Société Can. Sci. Pharm. 2014, 17, 1-19. [CrossRef] [PubMed]

193. Wang, X.; Li, L.; Zhang, G. Impact of deoxynivalenol and kaempferol on expression of tight junction proteins at different stages of Caco-2 cell proliferation and differentiation. RSC Adv. 2019, 9, 34607-34616. [CrossRef]

194. Wang, X.; Li, L.; Zhang, G. A proteomic study on the protective effect of kaempferol pretreatment against deoxynivalenol-induced intestinal barrier dysfunction in a Caco-2 cell model. Food Funct. 2020, 11, 7266-7279. [CrossRef] 
195. Akbari, P.; Braber, S.; Varasteh, S.; Alizadeh, A.; Garssen, J.; Fink-Gremmels, J. The intestinal barrier as an emerging target in the toxicological assessment of mycotoxins. Arch. Toxicol. 2017, 91, 1007-1029. [CrossRef] [PubMed]

196. Alizadeh, A.; Akbari, P.; Varasteh, S.; Braber, S.; Malekinejad, H.; Fink-Gremmels, J. Ochratoxin A challenges the intestinal epithelial cell integrity: Results obtained in model experiments with Caco-2 cells. World Mycotoxin J. 2019, 12, 399-407. [CrossRef]

197. Pinton, P.; Nougayrède, J.P.; Del Rio, J.C.; Moreno, C.; Marin, D.E.; Ferrier, L.; Bracarense, A.P.; Kolf-Clauw, M.; Oswald, I.P. The food contaminant deoxynivalenol, decreases intestinal barrier permeability and reduces claudin expression. Toxicol. Appl. Pharmacol. 2009, 237, 41-48. [CrossRef]

198. Romero, A.; Ares, I.; Ramos, E.; Castellano, V.; Martínez, M.M.A.; Martínez-Larrañaga, M.R.; Anadón, A.; Martínez, M.M.A. Mycotoxins modify the barrier function of Caco-2 cells through differential gene expression of specific claudin isoforms: Protective effect of illite mineral clay. Toxicology 2016, 353-354, 21-33. [CrossRef]

199. Sun, H.; Chow, E.C.Y.; Liu, S.; Du, Y.; Pang, K.S. The Caco-2 cell monolayer: Usefulness and limitations. Expert Opin. Drug Metab. Toxicol. 2008, 4, 395-411. [CrossRef]

200. Ferruzza, S.; Scarino, M.L.; Gambling, L.; Natella, F.; Sambuy, Y. Biphasic effect of iron on human intestinal Caco-2 cells: Early effect on tight junction permeability with delayed onset of oxidative cytotoxic damage. Cell. Mol. Biol. 2003, 49, 89-99.

201. Videmann, B.; Tep, J.; Cavret, S.; Lecoeur, S. Epithelial transport of deoxynivalenol: Involvement of human P-glycoprotein (ABCB1) and multidrug resistance-associated protein 2 (ABCC2). Food Chem. Toxicol. 2007, 45, 1938-1947. [CrossRef]

202. Sergent, T.; Parys, M.; Garsou, S.; Pussemier, L.; Schneider, Y.J.; Larondelle, Y. Deoxynivalenol transport across human intestinal Caco-2 cells and its effects on cellular metabolism at realistic intestinal concentrations. Toxicol. Lett. 2006, 164, 167-176. [CrossRef] [PubMed]

203. Artursson, P.; Palm, K.; Luthman, K. Caco-2 monolayers in experimental and theoretical predictions of drug transport. Adv. Drug Deliv. Rev. 2012, 22, 280-289. [CrossRef]

204. Kadota, T.; Furusawa, H.; Hirano, S.; Tajima, O.; Kamata, Y.; Sugita-Konishi, Y. Comparative study of deoxynivalenol, 3-acetyldeoxynivalenol, and 15-acetyldeoxynivalenol on intestinal transport and IL-8 secretion in the human cell line Caco-2. Toxicol. In Vitro 2013, 27, 1888-1895. [CrossRef]

205. Sobral, M.M.C.; Faria, M.A.; Cunha, S.C.; Miladinovic, B.; Ferreira, I.M. Transport of mycotoxins across human gastric NCI-N87 and intestinal Caco-2 cell models. Food Chem. Toxicol. 2019, 131, 110595. [CrossRef] [PubMed]

206. Tep, J.; Videmann, B.; Mazallon, M.; Balleydier, S.; Cavret, S.; Lecoeur, S. Transepithelial transport of fusariotoxin nivalenol: Mediation of secretion by ABC transporters. Toxicol. Lett. 2007, 170, 248-258. [CrossRef] [PubMed]

207. Pfeiffer, E.; Kommer, A.; Dempe, J.S.; Hildebrand, A.A.; Metzler, M. Absorption and metabolism of the mycotoxin zearalenone and the growth promotor zeranol in Caco-2 cells in vitro. Mol. Nutr. Food Res. 2011, 55, 560-567. [CrossRef]

208. Cirlini, M.; Barilli, A.; Galaverna, G.; Michlmayr, H.; Adam, G.; Berthiller, F.; Dall'Asta, C. Study on the uptake and deglycosylation of the masked forms of zearalenone in human intestinal Caco-2 cells. Food Chem. Toxicol. 2016, 98, 232-239. [CrossRef]

209. Prosperini, A.; Meca, G.; Font, G.; Ruiz, M.J. Study of the cytotoxic activity of beauvericin and fusaproliferin and bioavailability in vitro on Caco-2 cells. Food Chem. Toxicol. 2012, 50, 2356-2361. [CrossRef]

210. De Angelis, I.; Friggè, G.; Raimondi, F.; Stammati, A.; Zucco, F.; Caloni, F. Absorption of Fumonisin B1 and aminopentol on an in vitro model of intestinal epithelium; the role of P-glycoprotein. Toxicon 2005, 45, 285-291. [CrossRef]

211. Berger, V.; Gabriel, A.F.; Sergent, T.; Trouet, A.; Larondelle, Y.; Schneider, Y.J. Interaction of ochratoxin A with human intestinal Caco-2 cells: Possible implication of a multidrug resistance-associated protein (MRP2). Toxicol. Lett. 2003, 140-141, 465-476. [CrossRef]

212. De Walle, J.V.; Sergent, T.; Piront, N.; Toussaint, O.; Schneider, Y.-J.; Larondelle, Y. Deoxynivalenol affects invitro intestinal epithelial cell barrier integrity through inhibition of protein synthesis. Toxicol. Appl. Pharmacol. 2010, 245, 291-298. [CrossRef] [PubMed] 
213. De Nijs, M.; Van Den Top, H.J.; Portier, L.; Oegema, G.; Kramer, E.; Van Egmond, H.P.; Hoogenboom, L.A.P. Digestibility and absorption of deoxynivalenol-3-B-glucoside in in vitro models. World Mycotoxin J. 2012, 5, 319-324. [CrossRef]

214. Schrickx, J.; Lektarau, Y.; Fink-Gremmels, J. Ochratoxin A secretion by ATP-dependent membrane transporters in Caco-2 cells. Arch. Toxicol. 2006, 80, 243-249. [CrossRef]

215. Tuntiteerawit, P.; Jarukamjorn, K.; Porasuphatana, S. The effect of green tea catechins on breast cancer resistance protein activity and intestinal efflux of aflatoxin B1 via breast cancer resistance protein in Caco-2 cells. Toxicol. Res. 2020, 36, 293-300. [CrossRef]

216. Li, X.; Mu, P.; Wen, J.; Deng, Y. Carrier-Mediated and Energy-Dependent Uptake and Efflux of Deoxynivalenol in Mammalian Cells. Sci. Rep. 2017, 7, 1-10. [CrossRef] [PubMed]

217. Li, X.; Mu, P.; Qiao, H.; Wen, J.; Deng, Y. JNK-AKT-NF-кB controls P-glycoprotein expression to attenuate the cytotoxicity of deoxynivalenol in mammalian cells. Biochem. Pharmacol. 2018, 156, 120-134. [CrossRef] [PubMed]

218. Ivanova, L.; Fæste, C.K.; Solhaug, A. Role of P-glycoprotein in deoxynivalenol-mediated in vitro toxicity. Toxicol. Lett. 2018, 284, 21-28. [CrossRef]

219. Anderle, P.; Niederer, E.; Rubas, W.; Hilgendorf, C.; Spahn-Langguth, H.; Wunderli-Allenspach, H.; Merkle, H.P.; Langguth, P. P-glycoprotein (P-gp) mediated efflux in Caco-2 cell monolayers: The influence of culturing conditions and drug exposure on P-gp expression levels. J. Pharm. Sci. 1998, 87, 757-762. [CrossRef]

220. Videmann, B.; Mazallon, M.; Prouillac, C.; Delaforge, M.; Lecoeur, S. ABCC1, ABCC2 and ABCC3 are implicated in the transepithelial transport of the myco-estrogen zearalenone and its major metabolites. Toxicol. Lett. 2009, 190, 215-223. [CrossRef]

221. Xu, R.; Karrow, N.A.; Shandilya, U.K.; Sun, L.H.; Kitazawa, H. In-vitro cell culture for efficient assessment of mycotoxin exposure, toxicity and risk mitigation. Toxins 2020, 12, 146. [CrossRef]

222. Gao, Y.; Li, S.; Wang, J.; Luo, C.; Zhao, S.; Zheng, N. Modulation of intestinal epithelial permeability in differentiated caco-2 cells exposed to aflatoxin M1 and ochratoxin a individually or collectively. Toxins 2018, 10, 13. [CrossRef] [PubMed]

223. Marin, D.; Motiu, M.; Taranu, I. Food Contaminant Zearalenone and Its Metabolites Affect Cytokine Synthesis and Intestinal Epithelial Integrity of Porcine Cells. Toxins 2015, 7, 1979-1988. [CrossRef] [PubMed]

224. Bouhet, S.; Hourcade, E.; Loiseau, N.; Fikry, A.; Roselli, M.; Galtier, P.; Mengheri, E.; Oswald, I.P.; Martinez, S.; Roselli, M.; et al. The mycotoxin fumonisin B1 alters the proliferation and the barrier function of porcine intestinal epithelial cells. Toxicol. Sci. 2004, 77, 165-171. [CrossRef]

225. Pinton, P.; Braicu, C.; Nougayrede, J.-P.; Laffitte, J.; Taranu, I.; Oswald, I.P. Deoxynivalenol Impairs Porcine Intestinal Barrier Function and Decreases the Protein Expression of Claudin-4 through a Mitogen-Activated Protein Kinase-Dependent Mechanism. J. Nutr. 2010, 140, 1956-1962. [CrossRef] [PubMed]

226. Madara, J.L. Regulation of the Movement of Solutes Across Tight Junctions. Annu. Rev. Physiol. 1998, 60, 143-159. [CrossRef]

227. Gao, Y.N.; Wang, J.Q.; Li, S.L.; Zhang, Y.D.; Zheng, N. Aflatoxin M1 cytotoxicity against human intestinal Caco-2 cells is enhanced in the presence of other mycotoxins. Food Chem. Toxicol. 2016, 96, 79-89. [CrossRef]

228. Fleck, S.C.; Pfeiffer, E.; Metzler, M. Permeation and metabolism of Alternaria mycotoxins with perylene quinone structure in cultured Caco-2 cells. Mycotoxin Res. 2014, 30, 17-23. [CrossRef]

229. González-Arias, C.A.; Marín, S.; Rojas-García, A.E.; Sanchis, V.; Ramos, A.J. UPLC-MS/MS analysis of ochratoxin A metabolites produced by Caco-2 and HepG2 cells in a co-culture system. Food Chem. Toxicol. 2017, 109, 333-340. [CrossRef]

230. Matter, K.; Balda, M.S. Signalling to and from tight junctions. Nat. Rev. Mol. Cell Biol. 2003, 4, $225-237$. [CrossRef]

231. Moon, Y. Vomitoxin-Induced Cyclooxygenase-2 Gene Expression in Macrophages Mediated by Activation of ERK and p38 but Not JNK Mitogen-Activated Protein Kinases. Toxicol. Sci. 2002, 69, 373-382. [CrossRef]

232. Zhou, H.-R.; Jia, Q.; Pestka, J.J. Ribotoxic Stress Response to the Trichothecene Deoxynivalenol in the Macrophage Involves the Src Family Kinase Hck. Toxicol. Sci. 2005, 85, 916-926. [CrossRef] 
233. Pinton, P.; Graziani, F.; Pujol, A.; Nicoletti, C.; Paris, O.; Ernouf, P.; Di Pasquale, E.; Perrier, J.; Oswald, I.P.; Maresca, M. Deoxynivalenol inhibits the expression by goblet cells of intestinal mucins through a PKR and MAP kinase dependent repression of the resistin-like molecule $\beta$. Mol. Nutr. Food Res. 2015, 59, 1076-1087. [CrossRef] [PubMed]

234. Morrison, D.K. MAP Kinase Pathways. Cold Spring Harb. Perspect. Biol. 2012, 4, a011254. [CrossRef] [PubMed]

235. Lee, J.Y.; Lim, W.; Park, S.; Kim, J.; You, S.; Song, G. Deoxynivalenol induces apoptosis and disrupts cellular homeostasis through MAPK signaling pathways in bovine mammary epithelial cells. Environ. Pollut. 2019, 252, 879-887. [CrossRef] [PubMed]

236. Bouhet, S.; Le, E.; Peres, S.; Fairbrother, J.M.; Oswald, I.P.; Hyacinthe, S. Mycotoxin fumonisin B 1 selectively down-regulates the basal IL-8 expression in pig intestine: In vivo and in vitro studies. Food Chem. Toxicol. 2006, 44, 1768-1773. [CrossRef]

237. Beisl, J.; Pahlke, G.; Abeln, H.; Ehling-Schulz, M.; Del Favero, G.; Varga, E.; Warth, B.; Sulyok, M.; Abia, W.; Ezekiel, C.N.; et al. Combinatory effects of cereulide and deoxynivalenol on in vitro cell viability and inflammation of human Caco-2 cells. Arch. Toxicol. 2020, 94, 833-844. [CrossRef]

238. Pellegrina, C.D.; Perbellini, O.; Scupoli, M.T.; Tomelleri, C.; Zanetti, C.; Zoccatelli, G.; Fusi, M.; Peruffo, A.; Rizzi, C.; Chignola, R. Effects of wheat germ agglutinin on human gastrointestinal epithelium: Insights from an experimental model of immune/epithelial cell interaction. Toxicol. Appl. Pharmacol. 2009, 237, 146-153. [CrossRef]

239. Gao, Y.; Ye, Q.; Bao, X.; Huang, X.; Wang, J.; Zheng, N. Transcriptomic and proteomic profiling reveals the intestinal immunotoxicity induced by aflatoxin M1 and ochratoxin A. Toxicon 2020, 180, 49-61. [CrossRef]

240. Trapecar, M.; Cencic, A. Application of Gut Cell Models for Toxicological and Bioactivity Studies of Functional and Novel Foods. Foods 2014, 1, 40-51. [CrossRef]

241. Fu, J.; Cui, Y. In vitro digestion/Caco-2 cell model to estimate cadmium and lead bioaccessibility/bioavailability in two vegetables: The influence of cooking and additives. Food Chem. Toxicol. 2013, 59, 215-221. [CrossRef]

242. Ekmekcioglu, C. A physiological approach for preparing and conducting intestinal bioavailability studies using experimental systems. Food Chem. 2002, 76, 225-230. [CrossRef]

243. Seithel, A.; Karlsson, J.; Hilgendorf, C.; Bj, A.; Ungell, A.-L.; Björquist, A.; Ungell, A.-L. Variability in mRNA expression of ABC- and SLC-transporters in human intestinal cells: Comparison between human segments and Caco-2 cells. Eur. J. Pharm. Sci. 2006, 28, 291-299. [CrossRef] [PubMed]

244. Taipalensuu, J.; Törnblom, H.; Lindberg, G.; Einarsson, C.; Sjöqvist, F.; Melhus, H.; Garberg, P.; Sjöström, B.; Lundgren, B.; Artursson, P. Correlation of Gene Expression of Ten Drug Efflux Proteins of the ATP-Binding Cassette Transporter Family in Normal Human Jejunum and in Human Intestinal Epithelial Caco-2 Cell Monolayers. J. Pharmacol. Exp. Ther. 2001, 299, 164-170. [PubMed]

245. Lampen, A.; Bader, A.; Bestmann, T.; Winkler, M.; Witte, L.; Borlak, J.T. Catalytic activities, protein- and mRNA-expression of cytochrome P450 isoenzymes in intestinal cell lines. Xenobiotica 1998, 28, 429-441. [CrossRef] [PubMed]

246. Caloni, F.; Cortinovis, C.; Pizzo, F.; De Angelis, I. Transport of aflatoxin M1 in human intestinal Caco-2/TC7 cells. Front. Pharmacol. 2012, 3, 111. [CrossRef]

247. Wu, C.; Gao, Y.; Li, S.; Huang, X.; Bao, X.; Wang, J.; Zheng, N. Modulation of intestinal epithelial permeability and mucin mRNA (MUC2, MUC5AC, and MUC5B) expression and protein secretion in Caco-2/HT29-MTX co-cultures exposed to aflatoxin M1, ochratoxin A, and zearalenone individually or collectively. Toxicol. Lett. 2019, 309, 1-9. [CrossRef]

(C) 2020 by the authors. Licensee MDPI, Basel, Switzerland. This article is an open access article distributed under the terms and conditions of the Creative Commons Attribution (CC BY) license (http://creativecommons.org/licenses/by/4.0/). 